\title{
Exogenous $A \beta$ seeds induce $A \beta$ depositions in the blood vessels rather than the brain parenchyma, independently of $A \beta$ strain-specific information
}

Tsuyoshi Hamaguchi', Jee Hee Kim ${ }^{1}$, Akane Hasegawa ${ }^{1}$, Ritsuko Goto ${ }^{1}$, Kenji Sakai ${ }^{1}$, Kenjiro Ono ${ }^{1,2}$, Yoshinori Itoh ${ }^{3}$ and Masahito Yamada ${ }^{1,4^{*}}$ (1)

\begin{abstract}
Little is known about the effects of parenchymal or vascular amyloid $\beta$ peptide $(A \beta)$ deposition in the brain. We hypothesized that $A \beta$ strain-specific information defines whether $A \beta$ deposits on the brain parenchyma or blood vessels. We investigated 12 autopsied patients with different severities of $A \beta$ plaques and cerebral amyloid angiopathy (CAA), and performed a seeding study using an Alzheimer's disease (AD) mouse model in which brain homogenates derived from the autopsied patients were injected intracerebrally. Based on the predominant pathological features, we classified the autopsied patients into four groups: $A D, C A A, A D+C A A$, and less $A \beta$. One year after the injection, the pathological and biochemical features of $A \beta$ in the autopsied human brains were not preserved in the human brain extract-injected mice. The CAA counts in the mice injected with all four types of human brain extracts were significantly higher than those in mice injected with PBS. Interestingly, parenchymal and vascular A $\beta$ depositions were observed in the mice that were injected with the human brain homogenate from the less $A \beta$ group. The $A \beta$ and CAA seeding activities, which had significant positive correlations with the $A \beta$ oligomer ratio in the human brain extracts, were significantly higher in the human brain homogenate from the less $A \beta$ group than in the other three groups. These results indicate that exogenous $A \beta$ seeds from different $A \beta$ pathologies induced $A \beta$ deposition in the blood vessels rather than the brain parenchyma without being influenced by $A \beta$ strain-specific information, which might be why CAA is a predominant feature of $A \beta$ pathology in iatrogenic transmission cases. Furthermore, our results suggest that iatrogenic transmission of $A \beta$ pathology might occur due to contamination of brain tissues from patients with little $A \beta$ pathology, and the development of inactivation methods for $A \beta$ seeding activity to prevent iatrogenic transmission is urgently required.
\end{abstract}

Keywords: Amyloid $\beta$ peptide, Alzheimer's disease, Cerebral amyloid angiopathy, Transmission, Strain, latrogenic

*Correspondence: m-yamada@med.kanazawa-u.ac.jp

${ }^{1}$ Department of Neurology and Neurobiology of Aging, Kanazawa

University Graduate School of Medical Sciences, 13-1 Takara-machi, Kanazawa 920-8640, Japan

Full list of author information is available at the end of the article

\section{Introduction}

Alzheimer's disease (AD) is the most frequent cause of dementia, and senile plaques with extracellular deposition of amyloid $\beta$ peptides $(A \beta)$ and intracellular neurofibrillary tangles (NFTs) with abnormally phosphorylated tau protein are pathological hallmarks of AD [28]. Extracellular $\mathrm{A} \beta$ deposition is considered the primary pathological event in $A D$, because all genetic mutations in 
patients with inherited $A D$ have been found in genes related to $A \beta$ [55]. However, NFTs, and not $A \beta$ deposition, are significantly correlated with the progression of cognitive impairment [2].

Cerebral amyloid angiopathy (CAA) is a cerebrovascular amyloid deposition that causes normotensive cerebral haemorrhage in older individuals [63, 65]. Seven amyloid proteins that involve the vessels of patients with CAA have been reported, with $A \beta$ being the most common amyloid protein in patients with CAA [63, 65]. According to previous pathological studies, CAA is observed in approximately half of elderly individuals, and the incidence of CAA increases with age $[54,63,65,66]$. CAA is also common in $\mathrm{AD}$ patients, and the prevalence of CAA is $80 \%-90 \%$ in patients with $\mathrm{AD}[63,65,66]$. A $\beta$ is a 36-43 amino acid peptide cleaved from the amyloid precursor protein [8] by $\beta$-secretase and $\gamma$-secretase, and senile plaques mainly consist of 42-residue peptides $(\mathrm{A} \beta 42)$, whereas $\mathrm{A} \beta$ in $\mathrm{CAA}$ is mainly a 40 -residue variant $(A \beta 40)[63,65]$. A $\beta 40$ does not aggregate as easily as $A \beta 42$, whereas $A \beta 42$ promptly deposits in the brain parenchyma as senile plaques. $A \beta 40$ is considered to be cleared from the cerebral cortex through intramural periarterial drainage (IPAD) and glymphatic drainage pathways, in which $A \beta 40$ aggregates on vascular basement membranes [1, 3, 52, 61]. Although most patients with $\mathrm{CAA}$ have accompanying parenchymal $\mathrm{A} \beta$ deposition, there have been reports of pure CAA patients with fewer of $A \beta$ depositions or NFTs in the brain parenchyma, as well as AD patients presenting without CAA $[33,57,59]$. The precise reason why $\mathrm{A} \beta$ deposits in the brain parenchyma or blood vessels has not been elucidated.

Recently, under experimental settings, it has been established that neurodegenerative disorders characterized by the deposition of aberrant proteins, such as $A \beta$ and tau, in the brain can propagate to different cells via a prion-like mechanism, as well as to different regions within an individual and to different individuals [32]. In prion diseases, the pathological and physicochemical features of prion protein $(\operatorname{PrP})$ are maintained among individuals by strains of abnormal $\operatorname{PrP}\left(\operatorname{PrP}^{\mathrm{Sc}}\right)[10,11]$. Several studies have shown that differences in the molecular conformation of $A \beta$ correlate with pathological phenotypes of $A \beta$ pathology in the brains of $A D$ mouse models $[24,51,56,60]$, which suggests that $A \beta$ has several strains, similar to $\operatorname{Pr} \mathrm{P}^{\mathrm{Sc}}$.

Mutations in the amyloid precursor protein (APP) gene $(A P P)$ located around $\beta$ - and $\gamma$-secretase cleavage sites cause familial AD [7]. On the other hand, some mutations in the middle of $A P P$, such as E693Q for hereditary cerebral haemorrhage with amyloidosis (HCHWA)-Dutch type [42, 44] and E693K for HCHWA-Italian type [6], cause severe CAA with few parenchymal $A \beta$ depositions and NFTs. In HCHWA-Dutch patietns, the mutation of E693Q mutation leads to overproduction of $A \beta 40$, and an experimental study using a HCHWA-Dutch mouse model showed that an increase in the ratio of $A \beta 40 / A \beta 42$ in the brain homogenate plays an important role in the deposition of $A \beta$ on brain blood vessels [26, 27]. Different distributions of $\mathrm{A} \beta$ pathology among different point mutations of $A P P$ would show that structural differences of $A \beta$, in addition to the ratio of $A \beta 40 / A \beta 42$, might contribute to whether $A \beta$ deposits in brain parenchyma or vessels, which suggests that $A \beta$ strain-specific information would determine the distribution of $A \beta$ pathology.

We hypothesized that $A \beta$ strain-specific information defines whether $A \beta$ deposits in brain parenchyma or blood vessels in sporadic cases. To this end, in the present study, we performed a seeding study using an AD mouse model in which brain homogenates derived from patients with different severities of $A \beta$ plaques and CAA were injected intracerebrally. We then evaluated the pathological and biochemical features of the AD mouse model one year after injection.

\section{Materials and methods Autopsied patients}

We included 12 autopsied patients who died at Yokufukai Geriatric Hospital. All brain samples were collected from donors for whom written informed consent for the autopsy, as well as use of samples and clinical information for research purposes, were obtained. This study was approved by the institutional ethics committee of Kanazawa University (1276).

\section{Genetic analysis}

Genomic DNA extracted from patients' blood or frozen brains was used to analyze the polymorphism of the apolipoprotein E gene (APOE) [29].

\section{Neuropathology of the autopsied human brains}

Five- $\mu \mathrm{m}$-thick, formalin-fixed, paraffin-embedded tissue blocks of all patients were sectioned. Postmortem delay was generally less than $24 \mathrm{~h}$. Brain sections were stained with hematoxylin-eosin, Klüver-Barrera, Congo red, and Gallyas-Braak. Single-labelling immunohistochemical studies were performed on sections of the left frontal, parietal, temporal, and occipital lobes using antibodies against $\mathrm{A} \beta_{17-24}$ (4G8, 1:5,000; Covance), $\mathrm{A} \beta_{35-40}$ (1A10, 1:1,000; Immuno-Biological Laboratory), $A \beta_{1-42}$ (1:100; Immuno-Biological Laboratory), and phosphorylated tau (AT8, 1:1,000; Innogenetics) using the avidinbiotin-peroxidase complex (ABC) method (Vector) with diaminobenzidine as the chromogen. According to the manufacturer's datasheets, antibodies against $A \beta_{35-40}$ and $A \beta_{1-42}$ are human $A \beta 40$ specific (https://www.ibl-japan. 
co.jp/en/search/product/detail/id=3520) and human A 342 specific (https://www.ibl-japan.co.jp/en/search/ product $/$ detail/id $=3720$ ), respectively. Neuropathological analysis was performed by a scientist (KS) blinded to the clinical information of the patients. Neuropathological diagnosis was made using the Consortium to Establish a Registry for AD (CERAD) score [46], Thal phase [58], Braak AT8 stage [5], and CAA score [43]. Based on the pathological features, we classified the autopsied patients into four groups: $\mathrm{AD}, \mathrm{CAA}, \mathrm{AD}+\mathrm{CAA}$, and less $\mathrm{A} \beta$.

\section{Quantification of $A \beta$ pathology of the autopsied human brains}

All quantification was performed by a scientist (AH) blinded to the clinical information of the patients. The A $\beta$ loads (\% positive area stained with 4 G8), A $\beta 40$ loads (\% positive area stained with $1 \mathrm{~A} 10$ ), and $\mathrm{A} \beta 42$ loads (\% positive area stained with anti-A $\beta_{1-42}$ antibody) in the cortices of the frontal, parietal, temporal, and occipital lobes were quantified in 30 images per lobe (120 images per one patient) that were captured with a $20 \times$ objective under a bright field using an Olympus BX-51 microscope, Olympus DP71 digital camera, and WinROOF ${ }^{\circledR}$ customdesigned software (Mitani Corporation. Fukui, Japan).

\section{Preparation of the human brain tissue extracts}

The right occipital lobe from all autopsied patients was frozen on dry ice and stored at $-80{ }^{\circ} \mathrm{C}$ until the experiment. The brain samples were homogenized at $10 \%(\mathrm{w} / \mathrm{v})$ in PBS, vortexed, sonicated $3 \times 5 \mathrm{~s}$ and centrifuged at $3000 \times \mathrm{g}$ for $5 \mathrm{~min}$. The supernatant was divided into aliquots and frozen (human brain extracts). The PBS-insoluble pellet was sonicated in $5 \mathrm{M}$ guanidine and $50 \mathrm{mM}$ Tris- $\mathrm{HCl}$ of the same volume as PBS, solubilized by agitation at room temperature (around $25^{\circ} \mathrm{C}$ ) for $30 \mathrm{~min}$, and frozen (human brain pellets).

\section{Seeding study using transgenic mice}

Homozygous R1.40 APP-transgenic mice (R1.40 mice), which carry a yeast artificial chromosome containing the entire genomic copy of human APP harbouring the "Swedish" familial AD double mutation (APPK670NM671L) [40], were transferred from Tübingen University to Kanazawa University, and were generated by breeding the homozygous offspring. All animal studies were approved by the Institutional Animal Experiment Committee of Kanazawa University (AP-132607), and performed in accordance with the Guidelines for the Care and Use of Laboratory Animals at Kanazawa University (Kanazawa, Japan). A neuropathological study showed that both diffuse and cored plaques, as well as CAA, were observed in the brains of aged R1.40 mice [39].
Human brain extracts were injected into the brains of the R1.40 mice, as previously reported [19]. Threemonth-old homozygous R1.40 mice were anaesthetized with a mixture of ketamine/xylazine anaesthesia (ketamine $100 \mathrm{mg} / \mathrm{kg}$ and xylazine $10 \mathrm{mg} / \mathrm{kg}$ ), and bilateral stereotaxic injections of human brain extract were infused into the hippocampus $(2.5 \mu \mathrm{l})$ and overlying neocortex $(1.0 \mu \mathrm{l})(\mathrm{AP}-2.5 \mathrm{~mm}, \mathrm{~L} \pm 2.0 \mathrm{~mm}$, DV $-1.0 /-1.8 \mathrm{~mm}$ ). The surgical area was cleaned with sterile saline, the incision was sutured, and the mice were monitored until recovery from anaesthesia.

\section{Quantification of the $A \beta$ pathology of the $R 1.40$ mice brains}

The 15-month-old R1.40 mice were perfused transcardially with PBS under deep ketamine/xylazine anaesthesia (ketamine $400 \mathrm{mg} / \mathrm{kg}$ and xylazine $40 \mathrm{mg} / \mathrm{kg}$ ) one year after the injection of the human brain extract. The brains were harvested, hemidissected, and the left hemispheres were fixed in $4 \%$ paraformaldehyde for $24 \mathrm{~h}$ for histological studies, while the right hemispheres were frozen rapidly in liquid nitrogen and stored at $-80{ }^{\circ} \mathrm{C}$ for biochemical studies.

For assessing of $A \beta$ deposition in the brains of the R1.40 mice, 4\% paraformaldehyde-fixed, paraffin-embedded left hemispheres were sectioned in the coronal plane using a microtome at a thickness of $5 \mu \mathrm{m}$. Sections were routinely deparaffinized and hydrated in a graded series of ethanol, pre-treated with $99 \%$ formic acid for $5 \mathrm{~min}$, and immersed in $0.3 \%$ hydrogen peroxide and methanol for 30 min to block endogenous peroxidase before preblocking at ambient temperature with serum-free protein block (Dako, Glostrup, Denmark). A $\beta$ immunohistochemical staining was performed using antibodies against $A \beta_{17-24}$ (4G8, 1:5,000), $A \beta_{35-40}$ (1A10, 1:1,000), and $A \beta_{1-42}(1: 100)$ in conjunction with the Liquid $D A B$ Substrate Chromogen System (Dako. Glostrup, Denmark). $A \beta$ loads (\% positive area stained with 4G8), A $\beta 40$ loads (\% positive area stained with $1 \mathrm{~A} 10$ ), and $A \beta 42$ loads (\% positive area stained with anti- $\mathrm{A} \beta_{1-42}$ antibody) in the brain were quantified under a bright field using a Keyence BZ-700 microscope (Keyence Corporation, Osaka, Japan) and analyzed using a BZ-X analyzer (Keyence). The number of 4G8-positive blood vessels per $1 \mathrm{~mm}^{2}$ was also investigated (CAA counts). In total, five coronal sections were assessed by a scientist (JHK) who was blinded to the profile of each section of the mouse brain.

\section{Preparation of the R1.40 mice brain tissue homogenates}

The frozen R1.40 mouse brain samples were homogenized at $10 \%(\mathrm{w} / \mathrm{v})$ in PBS, vortexed, sonicated for $3 \times 5 \mathrm{~s}$, and centrifuged at $3000 \times \mathrm{g}$ for $5 \mathrm{~min}$. The supernatant was divided into aliquots and then frozen (mouse brain 
extracts). The PBS-insoluble pellet was sonicated in $5 \mathrm{M}$ guanidine and $50 \mathrm{mM}$ Tris- $\mathrm{HCl}$ of the same volume as PBS, solubilized by agitation at room temperature (around $25^{\circ} \mathrm{C}$ ) for $30 \mathrm{~min}$, and frozen (mouse brain pellets).

\section{Quantitative assessment of $A \beta$ in the brain}

To quantitatively assess $A \beta$ in the brain, a sandwich enzyme-linked immunosorbent assay (ELISA) was used to detect $\mathrm{A} \beta_{1-40}$ (Human $\beta$ Amyloid (1-40) ELISA Kit Wako II; FUJIFILM Wako Pure Chemical Corporation, Osaka, Japan) and $A \beta_{1-42}$ (Human $\beta$ Amyloid (1-42) ELISA Kit Wako, High-Sensitive; FUJIFILM Wako Pure Chemical Corporation, Osaka, Japan) in the human brain extracts, human brain pellets, mouse brain extracts, and mouse brain pellets according to the manufacturer's instructions.

\section{Analysis of A11-positive oligomers in the human brains}

To investigate A11-positive oligomers in the human brain extracts, dot blot assays were performed as described previously [21]. Human brain extracts were applied directly to a nitrocellulose membrane and air-dried, and the membrane was probed with an A11 antibody (1/1000, StressMarq Biosciences Inc. Victoria, Canada), which recognizes oligomers but not monomers or fibrils of several proteins that form amyloid, including $A \beta[18$, 37]. Immunoreactivity was quantified densitometrically using a LAS-4000 mini and Multi Gaurge Ver.3.X (Fujifilm, Tokyo, Japan). A11-positive $A \beta$ oligomers ranged in size from approximately tetramers to 20-mers [36]. Each sample was analyzed three times, and the values of A11-positive oligomers were indicated by each optical density divided by the average of all optical densities (value of A11-positive oligomers). The ratio of A11-positive oligomers in the human brain extract was calculated, and the value of A11-positive oligomers was divided by the concentration of $\mathrm{A} \beta 40+\mathrm{A} \beta 42$ (A11-positive oligomer ratio).

\section{Analysis of high molecular weight $A \beta$ oligomers in the human brains}

We investigated high molecular weight (HMW) A $\beta$ oligomers in the human brain extracts using an ELISA kit (High Molecular Amyloid $\beta$ Oligomer ELISA Kit Wako Ver. 2; FUJIFILM Wako Pure Chemical Corporation, Osaka, Japan) according to the manufacturer's instructions. This ELISA kit can detect mainly 10-20-mers of $A \beta$ oligomers, and the measured value is the value calculated based on a 16-mer multiple-antigenic peptides $[17,34]$. The ratio of HMW $A \beta$ oligomers in the $A \beta 40$ and $A \beta 42$ monomers was calculated by dividing the concentration of HMW A $\beta$ oligomers by the consentrations of $A \beta 40+A \beta 42$ (HMW $A \beta$ oligomer ratio).

\section{Calculation of $A B$ and CAA seeding activity in human autopsied patients}

The induction of $A \beta$ pathology in the brain extracts is dependent on the amount of $A \beta$ when the incubation period is the same [45]. We calculated the $A \beta$ and CAA seeding activities of the human brain extracts from autopsied patients as follows: the $\mathrm{A} \beta$ load and CAA counts in the human brain extract-injected R1.40 mice were divided by the concentrations of $A \beta 40+A \beta 42$ in the human brain extracts, as in a previous study [67].

\section{Proteinase $\mathrm{K}$ treatment of the human and mouse brain extracts}

The human and mouse brain extracts were treated with increasing concentrations $(0,25,50$, and $100 \mu \mathrm{g} / \mathrm{mL})$ of proteinase K (PK) (Nacalai Tesque, Inc., Kyoto, Japan) for $1 \mathrm{~h}$ at $37^{\circ} \mathrm{C}$. PK treatment was blocked by adding NuPage LDS Sample Buffer (Thermo Fisher Scientific, Inc., Massachusetts, USA) and NuPage Sample Reducing Agent (Thermo Fisher Scientific, Inc.), and then incubated for $10 \mathrm{~min}$ at $70{ }^{\circ} \mathrm{C}$. The samples were analyzed by Western blotting using NuPage 4-12\% Bis-Tris Gel using NuPage MES running buffer (Thermo Fisher Scientific, Inc.) and antibodies against $A \beta_{1-16}$ (6E10, 1:2,000; BioLegend) as the primary antibodies.

\section{Statistical analysis}

All values are expressed as means \pm standard deviation (SD). Differences in $A \beta$ loads, $A \beta 40$ loads, $A \beta 42$ loads, and CAA counts, concentrations of $A \beta 40, A \beta 42$, and $A \beta 40+A \beta 42$, and $A \beta 40 / A \beta 42$ ratios in mouse brain extracts and mouse brain pellets were compared among the five groups: the R1.40 mice injected with human brain extracts from the patients in the $\mathrm{AD}$ group (R1.40 mice-AD), R1.40 mice injected with human brain extracts from the patients in the CAA group (R.140 mice-CAA), R1.40 mice injected with human brain extracts from the patients in the AD+CAA group (R.140 mice-AD + CAA), R1.40 mice injected with human brain extracts from the patients in the less $A \beta$ group (R1.40 mice-less $A \beta$ ), and R1.40 mice injected with PBS (R1.40 mice-PBS). The differences were analyzed using oneway ANOVA followed by a Bonferroni post hoc analysis. Differences among the groups of autopsied patients in terms of $A \beta$ and CAA seeding activity were analyzed using a one-way ANOVA followed by a Bonferroni post hoc analysis. Correlations between $A \beta$ seeding activity and $A 11$-positive oligomer ratios, $A \beta$ seeding activity and HMW A $\beta$ oligomer ratios, CAA seeding activity and A11-positive oligomer ratios, and CAA seeding activity, 
and HMW A $\beta$ oligomer ratios were analyzed using Pearson's correlation tests. Statistical significance was defined as $P<0.05$. Statistical analyses were performed using IBM SPSS Statistics version 25 (SPSS Japan Inc. Tokyo, Japan).

\section{Results}

\section{Neuropathological findings of autopsied patients}

A summary of the 12 autopsied patients in the present study is shown in Table 1. Based on the pathological features, all patients were classified into four groups as follows: AD group (Patients 1-3), CAA group (Patients 4-6), AD + CAA group (Patients 7-10), and less $A \beta$ group (Patients 11 and 12). The ages at death were 79-92 years old, and 10 patients were analyzed for the $A p o E$ genotype; seven patients were $A p o E 3 / 3$, two patients were $A p o E$ 3/4, and one patient was ApoE 2/3 (Table 1).

Neuropathological studies of $A \beta$ pathology in representative patients are shown in Fig. 1 . In the $A D$ group, many cored and diffuse plaques were observed in the cerebral cortices, whereas CAA was hardly detected (Fig. 1a-c). Most $A \beta$ pathologies consisted of A $\beta 42$ (Fig. 1c), but little $A \beta 40$ pathology was observed (Fig. 1b). The cored plaques were stained with Congo red and displayed apple-green birefringence in polarized light, but diffuse plaques were not stained with Congo red (Fig. 1d). The CERAD score was $C$ in two patients and $B$ in another patient, the Thal phase was five in all three patients, and the CAA scores ranged from 0 to 2 (Table 1). In the CAA group, we found many brain vessels with CAA as well as many diffuse plaques, although few cored plaques were observed (Fig. 1e-g). CAA consisted of both $A \beta 40$ and $A \beta 42$ (Fig. 1f and g), and diffuse plaques were stained mainly with $A \beta 42$
(Fig. 1g). The vessels with CAA were stained with Congo red, but almost no stained lesions were observed in the brain parenchyma (Fig. 1h). The CERAD score was 0 in two patients and $A$ in another patient, the Thal phase was 5 in two patients and 2 in another patient, and the CAA scores ranged from 4 to 8 (Table 1). In the $\mathrm{AD}+\mathrm{CAA}$ group, we observed both cored and diffuse plaques in the grey matter as well as many vessels with CAA (Fig. 1i-k). Most of the cored and diffuse plaques were stained with $A \beta 42$, not $A \beta 40$ (Fig. $1 j$ and $k$ ), and the CAA consisted of both $A \beta 40$ and $A \beta 42$ (Fig. 1j and $\mathrm{k}$ ). The cored plaques and vessels with CAA were stained with Congo red (Fig. 11). The CERAD score was $B$ in two patients and $C$ in the other two patients, the Thal phase was 5 in all four patients, and the CAA score was 8 in all four patients (Table 1 ). In the less $A \beta$ group, small amounts of diffuse and cored plaques with slight CAA accumulation in the frontal and occipital lobes were observed in Patient 11. In Patient 12, there were few diffuse plaques and vessels with CAA (Fig. $1 \mathrm{~m}-\mathrm{p}$ ). The CERAD score was 0 in all two patients, the Thal phase was 1 and 3, and the CAA score ranged from 1 to 2 (Table 1). We did not observe the pathological findings of the right occipital lobe that was used for the human brain extracts that were injected into the R1.40 mice brains.

Neuropathological studies of tau pathology in representative patients are shown in Fig. 2. In the AD group, many neurofibrillary tangles (NFTs) and neuropil threads with dystrophic neurites were observed (Fig. 2a and $b$ ). In the CAA group, only a few pretangles were observed (Fig. 2c and d). In the AD + CAA group, many NFTs, neuropil threads and dystrophic neurites were observed (Fig. 2e and $f$ ). In the less $A \beta$ group, many

Table 1 Summary of autopsied patients

\begin{tabular}{|c|c|c|c|c|c|c|c|c|}
\hline $\mathrm{Pt}$ & $\begin{array}{l}\text { Age at death } \\
\text { (yrs) }\end{array}$ & Sex & ApoE genotype & CERAD score & Thal phase & $\begin{array}{l}\text { Braak AT8 } \\
\text { stage }\end{array}$ & CAA score & Type \\
\hline 1 & 79 & male & $3 / 4$ & C & 5 & 5 & 2 & $A D$ \\
\hline 2 & 87 & female & ND & C & 5 & 5 & 1 & $A D$ \\
\hline 3 & 92 & female & ND & B & 5 & 5 & 0 & $A D$ \\
\hline 4 & 85 & male & $2 / 3$ & 0 & 2 & 2 & 4 & CAA \\
\hline 5 & 87 & female & $3 / 3$ & 0 & 5 & 2 & 8 & CAA \\
\hline 6 & 91 & male & $3 / 4$ & A & 5 & 3 & 8 & CAA \\
\hline 7 & 81 & female & $3 / 3$ & C & 5 & 4 & 8 & $A D+C A A$ \\
\hline 8 & 89 & male & $3 / 3$ & B & 5 & 5 & 8 & $A D+C A A$ \\
\hline 9 & 80 & female & $3 / 3$ & B & 5 & 5 & 8 & $A D+C A A$ \\
\hline 10 & 89 & female & $3 / 3$ & C & 5 & 5 & 8 & $A D+C A A$ \\
\hline 11 & 86 & female & $3 / 3$ & 0 & 3 & 2 & 1 & less $A \beta$ \\
\hline 12 & 82 & male & $3 / 3$ & 0 & 1 & 2 & 2 & less $A \beta$ \\
\hline
\end{tabular}

Pt., patients; yrs, year; $A p o E$, apolipoprotein E; ND, not done; AD, Alzheimer's disease; CAA, cerebral amyloid angiopathy; $A \beta$, amyloid $\beta$ protein 


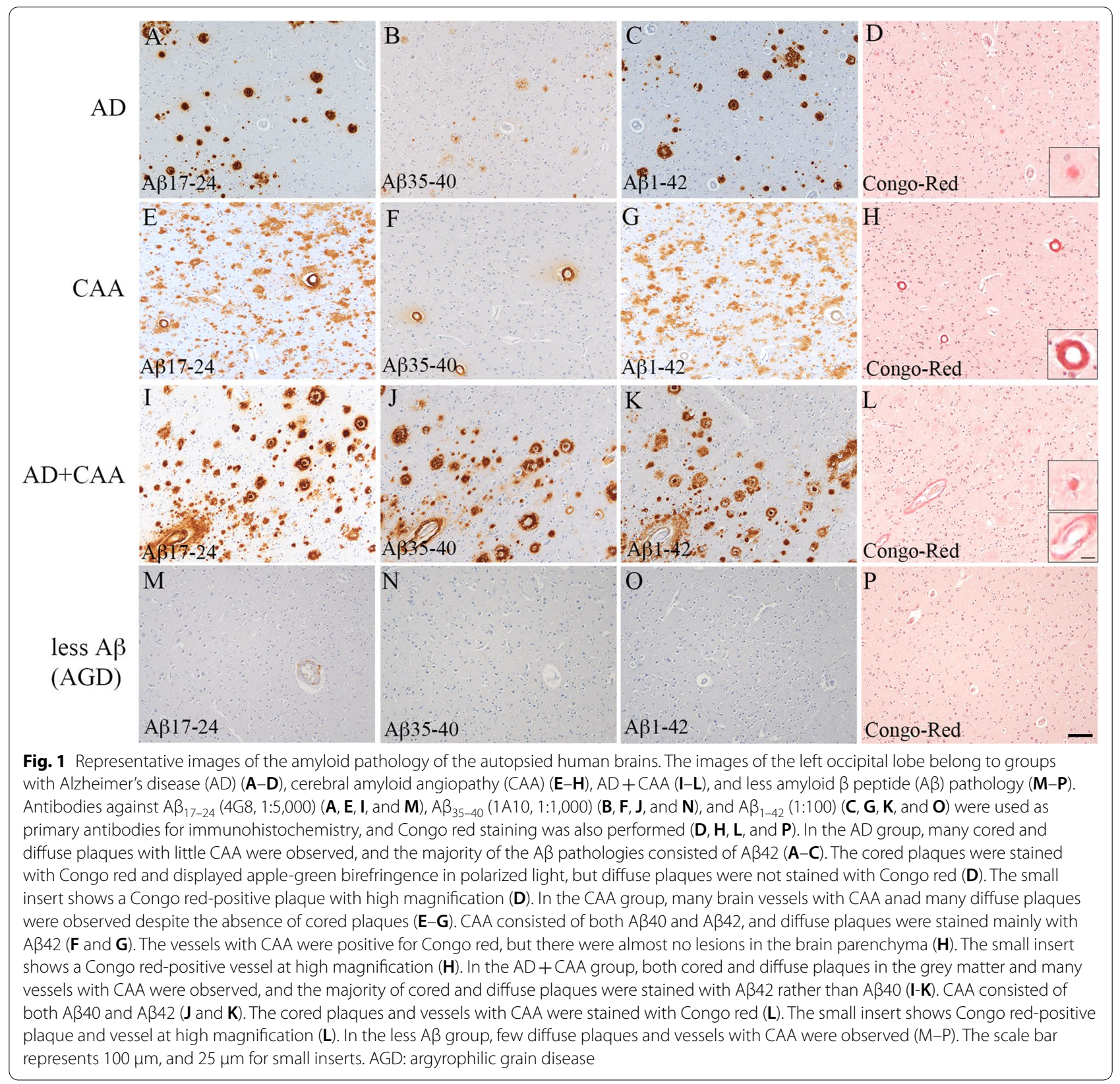

grains with some pretangles were observed (Fig. $2 \mathrm{~g}$ and h). According to neuropathological studies, both of the 2 patients in the less $A \beta$ group had argyrophilic grain disease (AGD).

A quantitative analysis of $A \beta$ pathology in autopsied patients is shown in Fig. 3. In the less $A \beta$ group, $A \beta$, $A \beta 40$, and $A \beta 42$ loads were much lower than those in the other three groups, but statistical analyses were not performed because of the small number of patients in each group (AD group, 3; CAA group, 3; AD + CAA group, 4 ; less $A \beta$ group, 2). The CAA scores of the CAA and $\mathrm{AD}+\mathrm{CAA}$ groups were higher than those of the $A D$ and less $A \beta$ groups (Fig. 3D).

\section{Concentration of $A \beta$ in the human brain extracts and human brain pellets}

In the human brain extracts, concentrations of $A \beta 40$ in the $\mathrm{CAA}$ and $\mathrm{AD}+\mathrm{CAA}$ groups were much higher than those in the $A D$ and less $A \beta$ groups, and consequently the concentrations of $A \beta 40+A \beta 42$ in the CAA and $\mathrm{AD}+\mathrm{CAA}$ groups were also much higher (Fig. $3 \mathrm{e}$ and $\mathrm{f}$ ). 


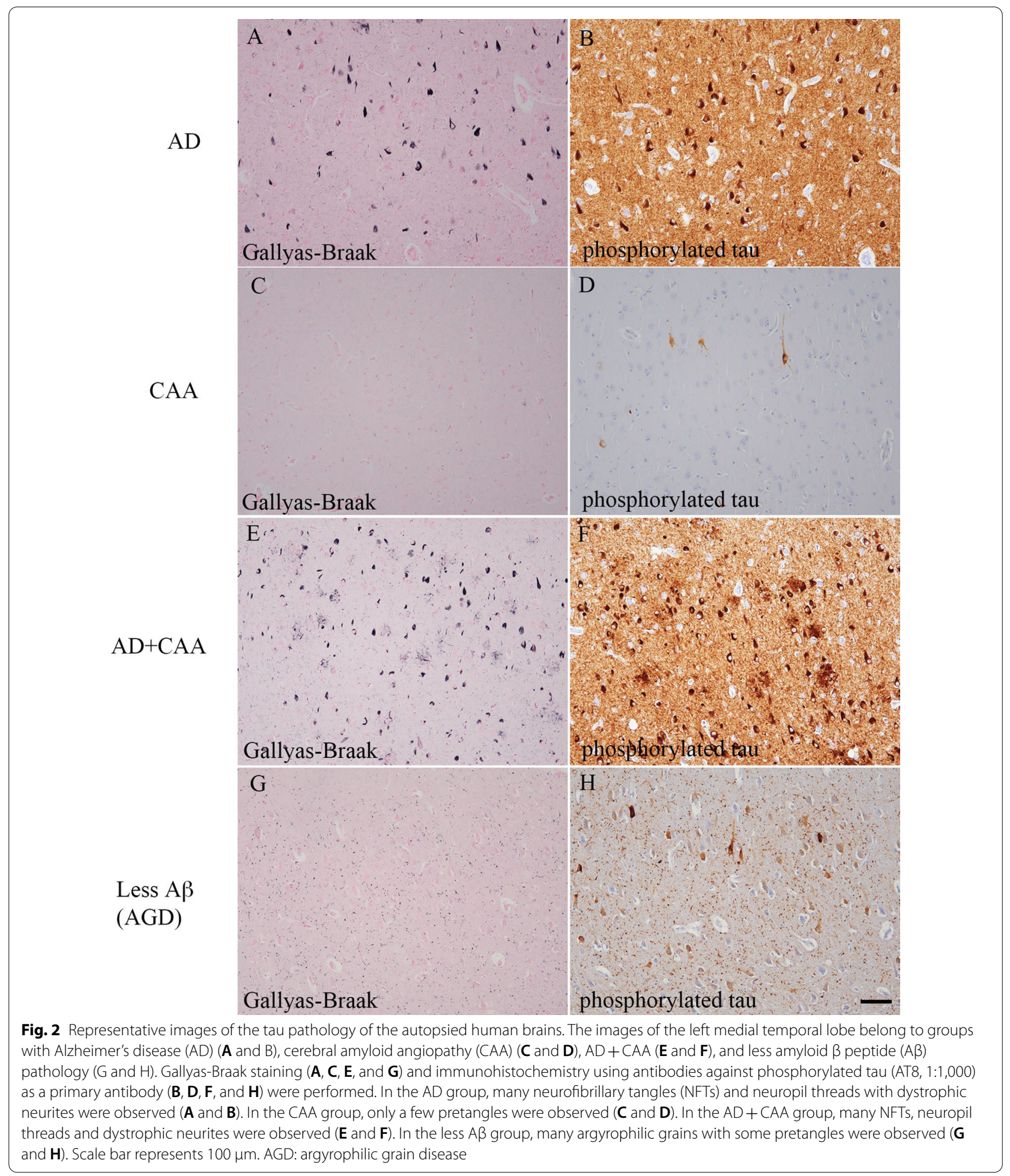

The concentrations of $A \beta 42$ in the CAA and AD + CAA groups were also higher than those in the $\mathrm{AD}$ and less $A \beta$ groups, but the differences were smaller than for the concentrations of $A \beta 40$ (Fig. 3g). The ratio of $A \beta 40 / A \beta 42$ was $\mathrm{A} \beta 42$-dominant in the patients with $\mathrm{AD}$ group, while it was $A \beta 40$ dominant in the other three groups (Fig. 3h).

In the human brain pellets, the proportion of the concentrations of $A \beta 40+A \beta 42, A \beta 40$, and $A \beta 42$, and the 

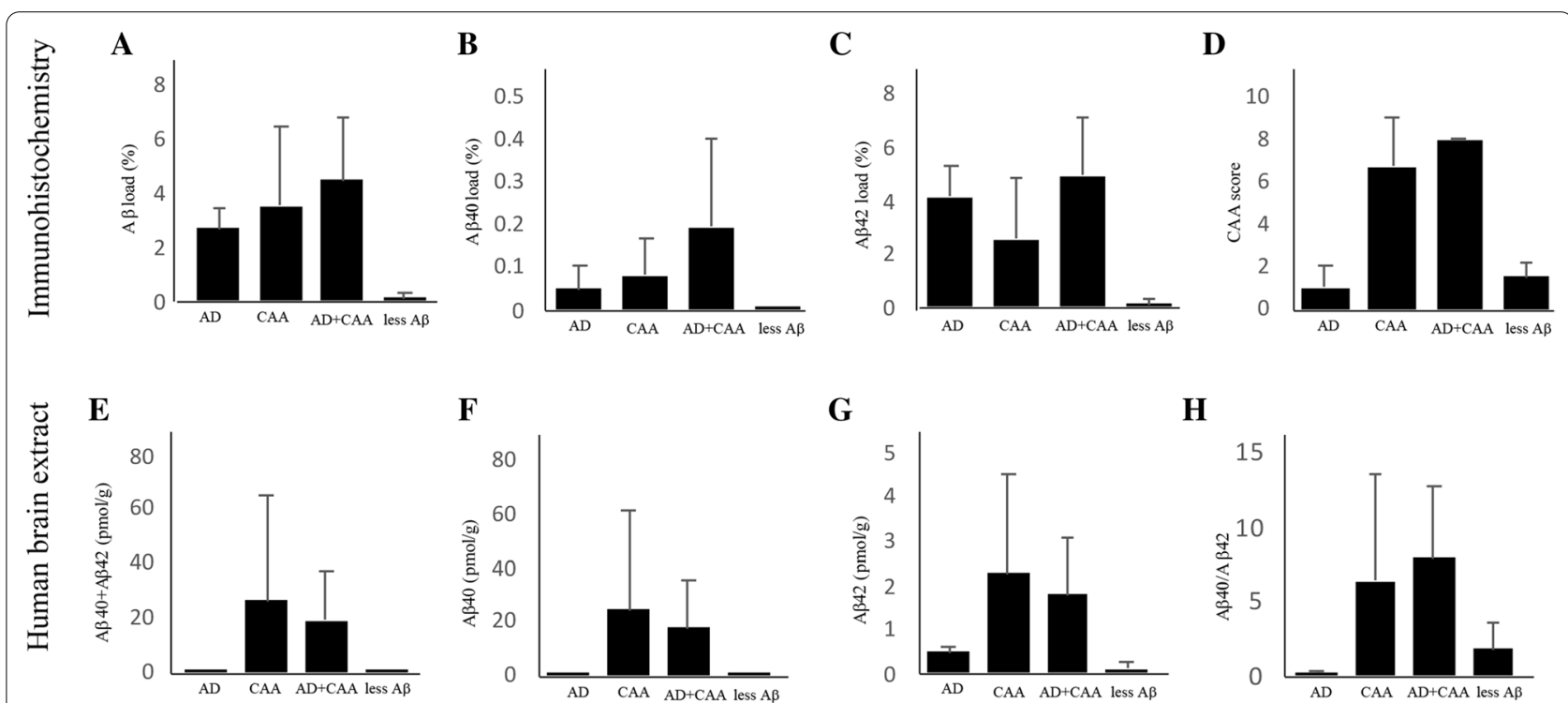

G

$\mathbf{H}$
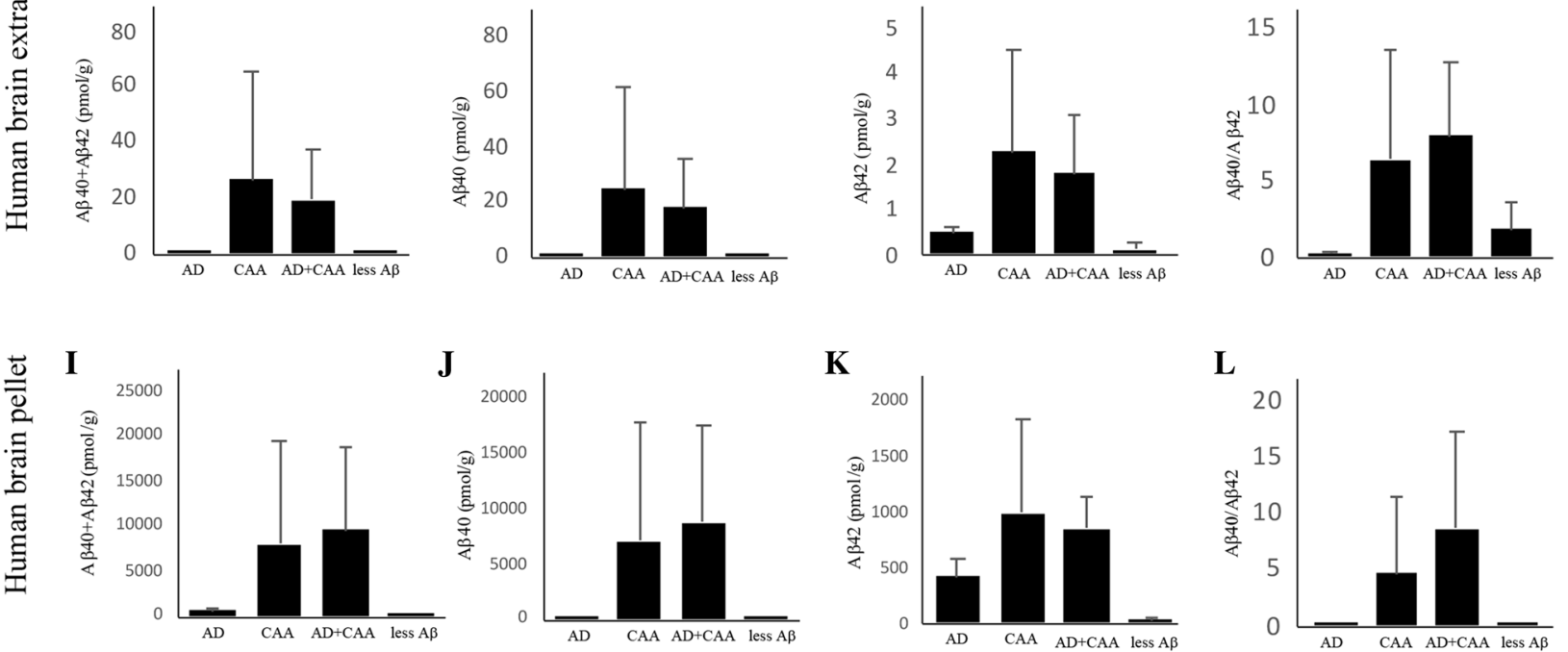

Fig. 3 Quantitative analysis of amyloid $\beta$ peptide $(A \beta)$ pathology and biochemical studies of the autopsied patients. The images represent the quantitative analysis of $A \beta$ pathology in the autopsied patients $(\mathbf{A}-\mathbf{D})$, and concentrations of $A \beta 40, A \beta 42$, and $A \beta 40+A \beta 42$, as well as the ratio of $A \beta 40 / A \beta 42$ in the human brain extracts $(\mathbf{E}-\mathbf{H})$ and human brain pellets (I-L). Compared to $A \beta$, the $A \beta 40$ and $A \beta 42$ loads in the Alzheimer's disease $(A D)$, cerebral amyloid angiopathy (CAA) and $A D+C A A$ groups, those with less $A \beta$ pathology were much lower $(\mathbf{A}-\mathbf{C})$. The CAA scores of the $C A A$ and the $A D+C A A$ groups were higher than those of the $A D$ and the less $A \beta$ groups $(\mathbf{D})$. In the human brain extracts, concentrations of $A \beta 40$ in the $C A A$ and $A D+C A A$ groups were much higher than those in the $A D$ and less $A \beta$ groups, and consequently the concentrations of $A \beta 40+A \beta 42$ in the CAA and $A D+C A A$ groups were also much higher $(\mathbf{E}$ and $\mathbf{F})$. The concentrations of $A \beta 42$ in the CAA and AD + CAA groups were also higher than those in the $A D$ and less $A \beta$ groups, but the differences were smaller than for the $A \beta 40$ concentrations $(\mathbf{G})$. The ratio of $A \beta 40 / A \beta 42$ was $A \beta 42$-dominant in the patients with $A D$ group, while that of the other three groups was $A \beta 40$ dominant $(\mathbf{H})$. In the human brain pellets, the proportion of the concentrations of $A \beta 40+A \beta 42, A \beta 40$, and $A \beta 42$, as well as the ratio of $A \beta 40 / A \beta 42$ among the $A D, C A A, A D+C A A$, and less $A \beta$ groups were similar to those in the human brain extracts $(I-L)$

ratio of $\mathrm{A} \beta 40 / \mathrm{A} \beta 42$ among the $\mathrm{AD}, \mathrm{CAA}, \mathrm{AD}+\mathrm{CAA}$, and less $A \beta$ groups were similar to those in the human brain extracts (Fig. 3i-l).

\section{A11-positive oligomers and HMW A $\beta$ oligomers in the human brain extracts}

In the analysis of A11-positive oligomers in the human brain extracts, the amount of A11-positive oligomers and the concentration of HMW A $\beta$ oligomers in the $\mathrm{AD}+\mathrm{CAA}$ group were slightly higher than in the other three groups (Fig. 4b and c). The A11-positive oligomer ratio and HMW $A \beta$ oligomer ratio in the less $A \beta$ group were higher than in the other three groups (Fig. $4 \mathrm{~d}$ and e). However, statistical analyses were not performed due to the small number of the patients.

\section{$\mathrm{A} \beta$ pathology in the R1.40 APP-transgenic mice 1 year after the injection of human brain homogenates}

The $A \beta$ pathology of the mouse brain 12 months after the injection of the human brain extracts is shown in Fig. 5 . The $A \beta$ pathology characteristics were similar in all four groups of mice injected with the human brain extracts. We found diffuse $A \beta$ plaques, not cored plaques, and CAA both in the cortices and hippocampi of all groups of mice injected with human brain extracts (Fig. 5a-c, $\mathrm{e}-\mathrm{g}, \mathrm{i}-\mathrm{k}, \mathrm{m}-\mathrm{o})$. The vessels with CAA were stained 
A

\begin{tabular}{|lrrrrr|}
\hline Patient 1 & Patient 2 & Patient 3 & Patient 4 & Patient 5 & Patient 6 \\
\hline Patient 7 & Patient 8 & Patient 9 & Patient 10 & Patient 11 & Patient 12 \\
\hline
\end{tabular}

B

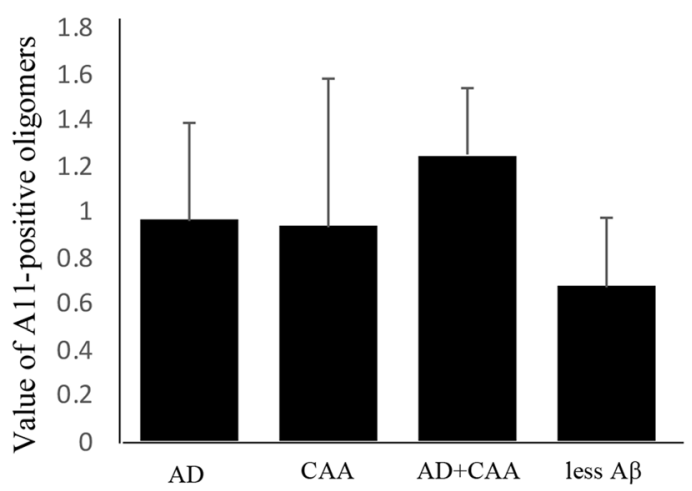

D

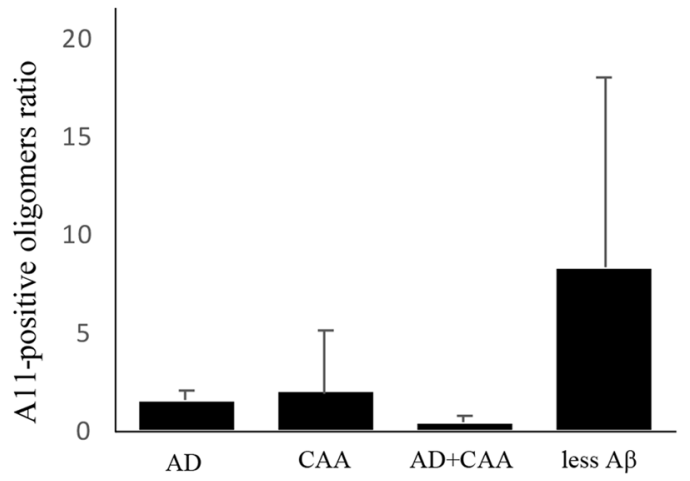

C

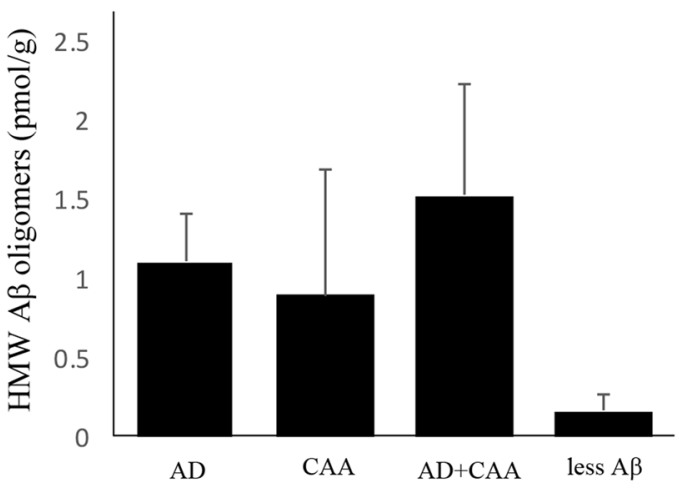

$\mathbf{E}$

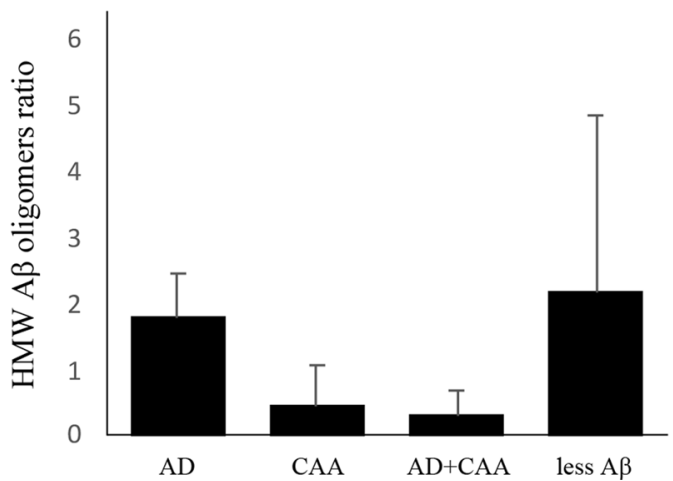

Fig. 4 A11-positive oligomers and high molecular weight (HMW) A $\beta$ oligomers in the human brain extracts. A11-positive oligomers for the Patient 1-12 in the Table 1 were anlayzed by dot blot analyses (A). Quantification of densitometry showed that the value of A11-positive oligomers in Alzheimer's disease (AD), cerebral amyloid angiopathy (CAA), and less A groups were slightly lower than those of the AD +CAA group (B). Similarly, the concentrations of HMW A $\beta$ oligomers in the AD + CAA group were slightly higher than those in the other three groups (C). The A11-positive oligomer ratio and HMW A $\beta$ oligomer ratio in the less $A \beta$ group were higher than those in the other three groups $(\mathbf{D}$ and $\mathbf{E})$

Congo red, but few Congo red-positive lesions were observed in the brain parenchyma (Fig. $5 \mathrm{~d}, \mathrm{~h}, \mathrm{l}$, and p). In PBS-injected mice, neither $\mathrm{A} \beta$ plaques nor $\mathrm{CAA}$ were observed (Fig. $5 q-t)$, which is consistent with our previous report [19].

The quantitative analysis of $\mathrm{A} \beta$ pathology in the human brain extract or PBS injected-R1.40 APP-transgenic mice is shown in Fig. 6. The $A \beta$ load in R1.40 mice-AD $(\mathrm{n}=22)$ was significantly higher than that in the $\mathrm{R} 1.40$ mice-CAA ( $\mathrm{n}=23), \mathrm{R} 1.40$ mice-AD + CAA $(\mathrm{n}=31)$, and R1.40 mice-PBS $(n=9)$, although there was no significant difference between R1.40 mice-AD and R1.40 mice-less $\mathrm{A} \beta(\mathrm{n}=14)$, and among R1.40 mice-CAA, R1.40 mice$\mathrm{AD}+\mathrm{CAA}$ and R1.40 mice-less $\mathrm{A} \beta$ (Fig. 6a). The A $\beta 42$ load in the R1.40 mice-AD was significantly higher than that in all other groups of R1.40 mice (Fig. 6c), while the 


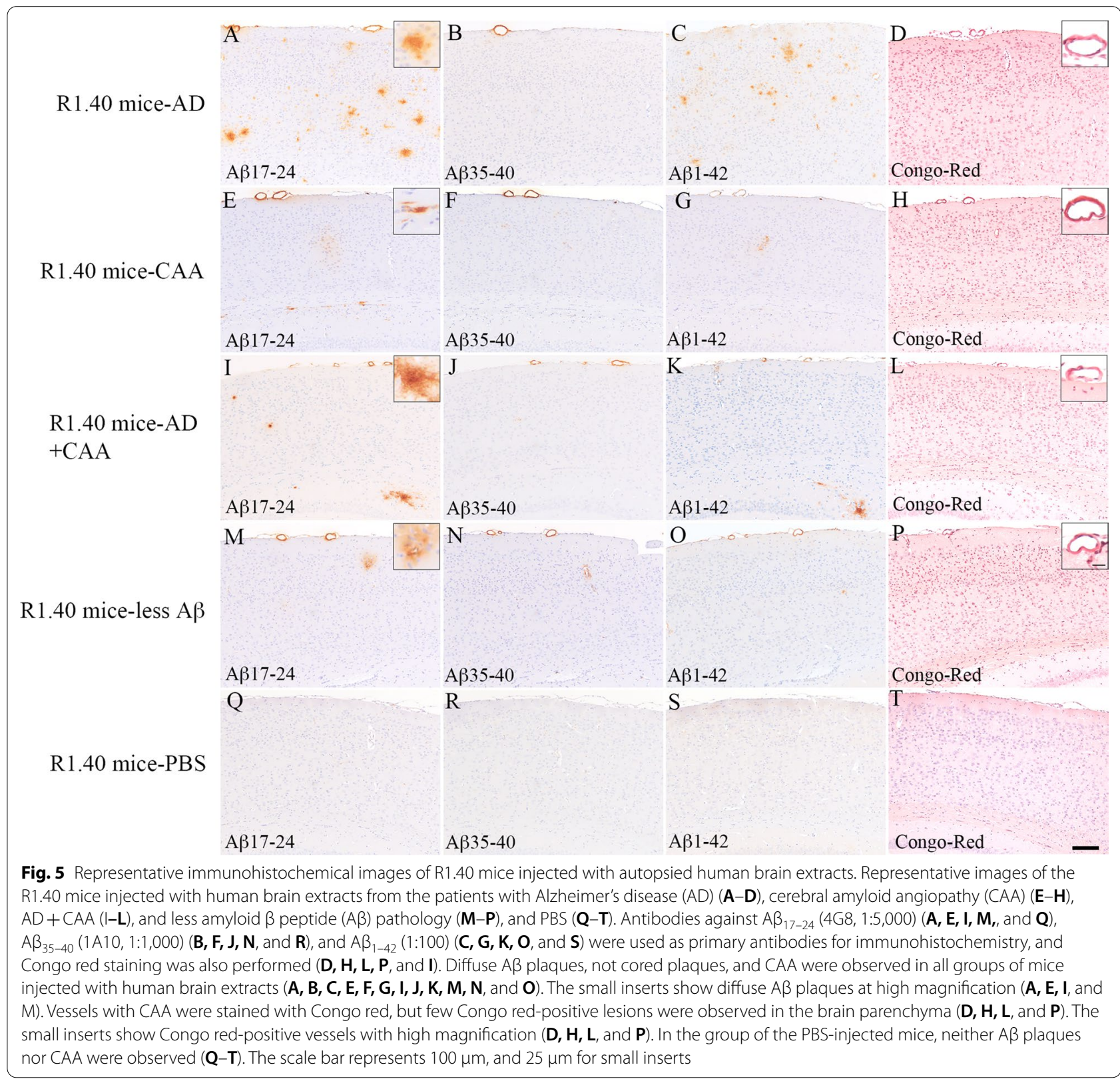

A $\beta 40$ load was not significantly different among them (Fig. 6b). The CAA count was not significantly different among the R1.40 mice-AD, R1.40 mice-CAA, R1.40 mice-AD + CAA, and R1.40 mice-less $A \beta$, although the CAA count in R1.40 mice-PBS was significantly lower than that in all other mice groups (Fig. 6d).

\section{Concentration of $A \beta$ in the mouse brain extracts and mouse brain pellets}

There was no significant difference in the concentration of $A \beta 40, A \beta 42$, or $A \beta 40+A \beta 42$ in the mouse brain extracts among R1.40 mice-AD, R1.40 mice-CAA, R1.40
mice-AD + CAA, and R1.40 mice-less A $\beta$ (Fig. 6e-g). The concentration of $A \beta 40+A \beta 42$ in R1.40 mice-PBS was significantly lower than in all other groups of R1.40 mice (Fig. 6e). The concentration of A $\beta 40$ in R1.40 mice-PBS was significantly lower than that in R1.40 mice-CAA, R1.40 mice-AD + CAA, and R1.40 mice-less A $\beta$ (Fig. 6f). The concentration of A $\beta 42$ in R1.40 mice-PBS was significantly lower than that in R1.40 mice-AD (Fig. 6g). The A $\beta 40 / A \beta 42$ ratio of $\mathrm{R} 1.40$ mice-PBS was significantly higher than that of R1.40 mice-AD, R1.40 mice-CAA, R1.40 mice-AD + CAA, and R1.40 mice-less $A \beta$, although the $A \beta 40 / A \beta 42$ ratio was not significantly different 

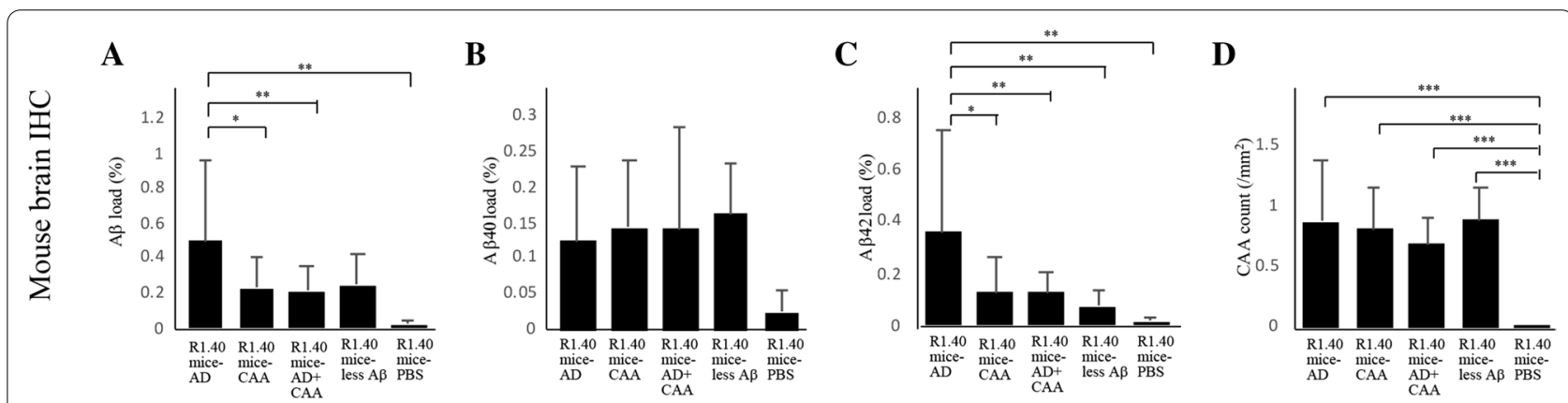

E
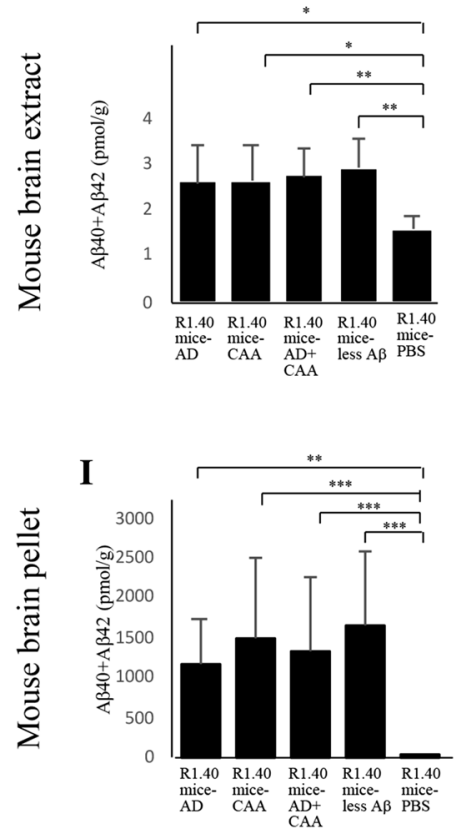

F

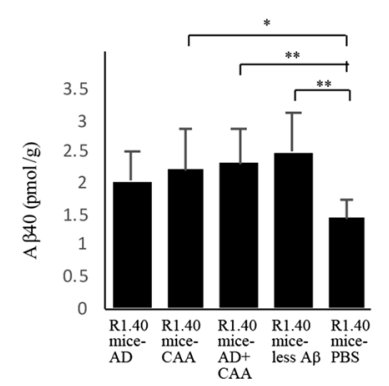

J

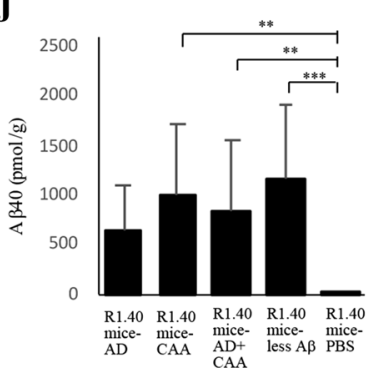

G

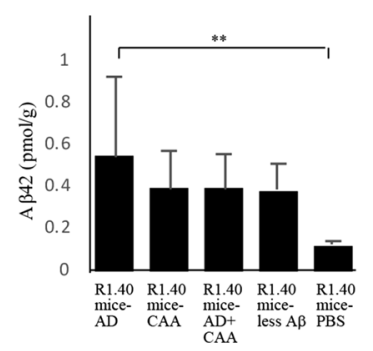

H

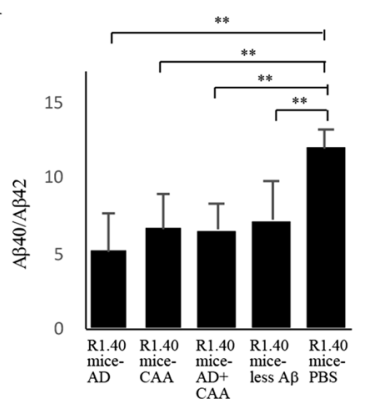

K

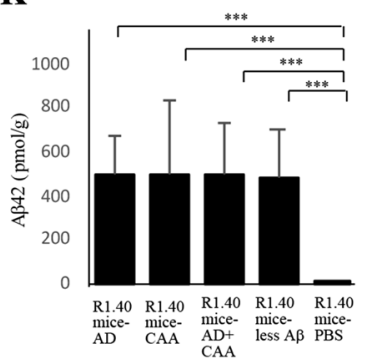

L

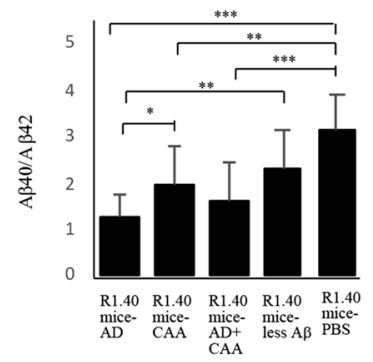

Fig. 6 Quantitative analysis of amyloid $\beta$ protein $(A \beta)$ pathology and biochemical studies in R1.40 mice. Quantitative analysis of the $A \beta$ pathology of the R1.40 mice injected with human brain extracts from the Alzheimer's disease (AD) (R1.40 mice-AD), cerebral amyloid angiopathy (CAA) (R1.40 mice-CAA), AD + CAA (R1.40 mice-AD+CAA), and less A pathology groups (R1.40 mice-less A $)$ ), and PBS (R1.40 mice-PBS) (A-D). Concentrations of $A \beta 40, A \beta 42$, and $A \beta 40+A \beta 42$, and ratio of $A \beta 40 / A \beta 42$ in the mouse brain extracts $(E-H)$ and in the mouse brain pellets (I-L). The $A \beta$ load in the R1.40 mice-AD was significantly higher than that in the R1.40 mice-CAA, R1.40 mice-AD + CAA, and R1.40 mice-PBS despite no significant difference in $A \beta$ loads between R1.40-AD and R1.40 mice-less A $\beta$ (A). The A 42 load was significantly higher in the R1.40 mice-AD than in all the other groups of R1.40 mice (C), while the $A \beta \beta 40$ load was not significantly different among them (B). CAA counts were not significantly different among the R1.40 mice-AD, R1.40 mice-CAA, R1.40 mice-AD + CAA, and R1.40 mice-less AB, although the CAA count in R1.40 mice-PBS was significantly lower than in all other mice groups (D). In the mouse brain extract, no significant difference in the concentrations of $A \beta 0, A \beta 42$, and $A \beta \beta 40+A \beta 42$ in the mouse brain extracts was observed among R1.40 mice-AD, R1.40 mice-CAA, R1.40 mice-AD + CAA, and R1.40 mice-less AB (E-G). Compared to R1.40 mice-PBS, concentrations of A 440 in R1.40 mice-CAA, R1.40 mice-AD + CAA, and R1.40 mice-less A ; that of A 342 in R1.40 mice-AD; and that of $A \beta 40+A \beta 42$ in R1.40 mice-AD, R1.40 mice-CAA, R1.40 mice-AD + CAA, and R1.40-less $A \beta$ were significantly higher (E-G). The $A \beta 40 / A \beta 42$ ratio of R1.40 mice-PBS was significantly higher than that of R1.40 mice-AD, R1.40 mice-CAA, R1.40 mice-AD+CAA and R1.40 mice-less A 3 , although the $A \beta 40 / A \beta 42$ ratio was not significantly different among the 4 groups of R1.40 mice injected with human brain extracts $(H)$. The $A \beta 40 / A \beta 42$ ratios of all groups of R1.40 mice were $A \beta 40$ dominant $(H)$. In the mouse brain pellets, the concentrations of $A \beta 40, A \beta 42$, or $A \beta 40+A \beta 42$ were not significantly different among R1.40 mice-AD, R1.40 mice-CAA, R1.40 mice-AD + CAA, and R1.40 mice-less A (I-K), although the concentrations of $A \beta 40+A \beta 42$ and $A \beta 42$ in R1.40 mice-PBS were significantly lower than those in all other groups (I and $K)$. The concentration of $A \beta 40$ in R1.40 mice-PBS was significantly lower than that in R1.40 mice-CAA, R1.40 mice-AD + CAA, and R1.40 mice-less A $(J)$. The A $340 / A \beta 42$ ratio of R1.40 mice-PBS was significantly higher than that of R1.40 mice-AD, R1.40 mice-CAA and R1.40 mice-AD +CAA, and the AB40/A 42 ratio of R1.40 mice-AD was significantly lower than that of $R 1.40$ mice-CAA and $R 1.40$ mice-less $A \beta(L)$. The $A \beta 40 / A \beta 42$ ratio of all groups of R1.40 mice indicated Aß40 dominance (L). ${ }^{*} p<0.01,{ }^{* *} p<0.05,{ }^{* * *} p<0.001$ 
among all four groups of human brain extract-injected R1.40 mice (Fig. $6 \mathrm{~h}$ ). The $A \beta 40 / A \beta 42$ ratio of all groups of R1.40 mice indicated A $\beta 40$ dominance (Fig. $6 \mathrm{~h}$ ).

In the mouse brain pellets, the concentrations of $A \beta 40$, $A \beta 42$, or $A \beta 40+A \beta 42$ were not significantly different among R1.40 mice-AD, R1.40 mice-CAA, R1.40 mice$\mathrm{AD}+\mathrm{CAA}$, and R1.40 mice-less $\mathrm{A} \beta$ (Fig. 6i-k). The concentrations of $A \beta 40+A \beta 42$ and $A \beta 42$ in R1.40 mice-PBS were significantly lower than those in all other groups of R1.40 mice (Fig. 6i and k). The concentration of $A \beta 40$ in R1.40 mice-PBS was significantly lower than that in R1.40 mice-CAA, R1.40 mice-AD+CAA, and R1.40 mice-less $A \beta$ (Fig. 6j). The $A \beta 40 / A \beta \beta 42$ ratio of $R 1.40$ mice-PBS was significantly higher than that of R1.40 mice-AD, R1.40 mice-CAA and R1.40 mice-AD+CAA, and the $\mathrm{A} \beta 40 / \mathrm{A} \beta 42$ ratio of $\mathrm{R} 1.40$ mice-AD was significantly lower than that of R1.40 mice-CAA and R1.40 mice-less $A \beta$ (Fig. 6l). The $A \beta 40 / A \beta 42$ ratio of all groups of $R 1.40$ mice indicated $A \beta 40$ dominance (Fig. 6l).

\section{$A \beta$ and CAA seeding activity}

$A \beta$ and CAA seeding activities in the less $A \beta$ group were significantly higher than those in the other three autopsied human patient groups (Fig. 7a and b). CAA seeding activity was significantly lower in the AD + CAA group than that in the CAA group (Fig. 7b). The A11-positive oligomer ratio and HMW $A \beta$ oligomer ratio, which were much higher in the less $A \beta$ group than in the other three groups (Fig. $4 \mathrm{c}$ and $d$ ), similar to the $A \beta$ and CAA seeding activities, had a significant positive correlation with the A11-positive oligomer ratio and HMW A $\beta$ oligomer ratio (Fig. $7 \mathrm{c}-\mathrm{f})$.

\section{PK resistance of $A \beta$ in the human and mouse brain extracts} In the human brain extracts, $A \beta$ oligomers were digested by PK in the all four groups (Fig. 8a). However, the signals of the $A \beta$ monomers and dimers were different among the four groups; the signals of the $A \beta$ monomers increased in the $\mathrm{AD}$ and $\mathrm{AD}+\mathrm{CAA}$ patient groups, those of the $A \beta$ dimers increased in the CAA group, and almost no $A \beta$ monomer and dimer signals were detected in the less $A \beta$ group (Fig. 8a). On the other hand, in the mouse brain extracts, $A \beta$ oligomers were digested and the signals of the $A \beta$ dimer were lightly present (Fig. 8b).

\section{Discussion}

In the present study, although the morphological features of $A \beta$ pathology, such as cored plaques, diffuse plaques, and CAA, were clearly different among the $\mathrm{AD}, \mathrm{CAA}, \mathrm{AD}+\mathrm{CAA}$ and less $\mathrm{A} \beta$ groups in the autopsied patients, those in the R1.40 mice injected with the human brain extracts were very similar among the four groups. In particular, the CAA scores of the AD and less
$A \beta$ groups were much lower than those of the CAA and $\mathrm{AD}+\mathrm{CAA}$ groups, while the CAA counts of the mice injected with human brain extracts were not significantly different among the four groups. Concerning the biochemical features of $A \beta$, the concentrations of $A \beta 42$ in the human brain extracts and pellets of the AD group were greater than the concentrations of $A \beta 40$, while those in the mouse brain extracts of the R1.40 mice-AD were the opposite. Furthermore, the $\mathrm{A} \beta \mathrm{PK}$ resistance of the human brain extracts was different among the different patient groups, which might be due to differences in the $A \beta$ strain, while the PK resistance in the mouse brain extracts was not different among the groups. These results indicated that the pathological and biochemical features of $A \beta$ in the autopsied human brains were not preserved in the R1.40 mice injected with human brain extracsts, which was contrary to the $A \beta$ strain hypothesis. Recently, several studies have shown that $A \beta$ fibrils from patients with $\mathrm{AD}$ have several structural variations $[38,50]$, and that the diversity of $A \beta$ pathology in mouse models and human brains might be dependent on different molecular architectures of $A \beta$ aggregates, which are the so-called $A \beta$ strains that are similar to prion strains $[24,45,51,56,60]$. In prion diseases, several different types of $\mathrm{PrP}^{\mathrm{Sc}}$ with different neuropathological and biochemical profiles despite identical PrP amino acid sequences have been reported, and the diversity of $\mathrm{PrP}^{\mathrm{Sc}}$ reflects differences in $\mathrm{PrP}^{\mathrm{Sc}}$ conformations, which are called prion strains $[23,48]$. Furthermore, there have been several types of prion diseases with different characteristics of clinical and neuropathological features, and these differences are influenced by prion strains and genetic variations of the PrP gene [23, 48]. Previous studies using animal models or patients with acquired prion diseases have shown that neuropathological and biochemical features of $\mathrm{PrP}^{\mathrm{Sc}}$ in donor subjects are preserved in host subjects, or novel prion strains with characteristics of both the donors and hosts have emerged $[23,48]$. However, the results of the present study showed that $A \beta$ deposition in brain parenchyma or blood vessels was not defined by $A \beta$ strain-specific information, suggesting the importance of $A \beta$ strains in the host or in $A \beta$ production and clearance.

In the present study, the CAA counts in the R1.40 mice injected with the human brain extracts from all four groups, including R1.40 mice-AD and -less $A \beta \beta$, were significantly higher than those in the R1.40 micePBS, although CAA was hardly detected in the patients with $A D$ and less $A \beta$ groups. On the other hand, regarding parenchymal $A \beta$ deposition in the $\mathrm{R} 1.40$ mice, $A \beta$ load was not different among the R1.40 mice injected with the human brain extract and PBS, except for significantly higher $A \beta$ and $A \beta 42$ loads in R1.40 mice-AD. 

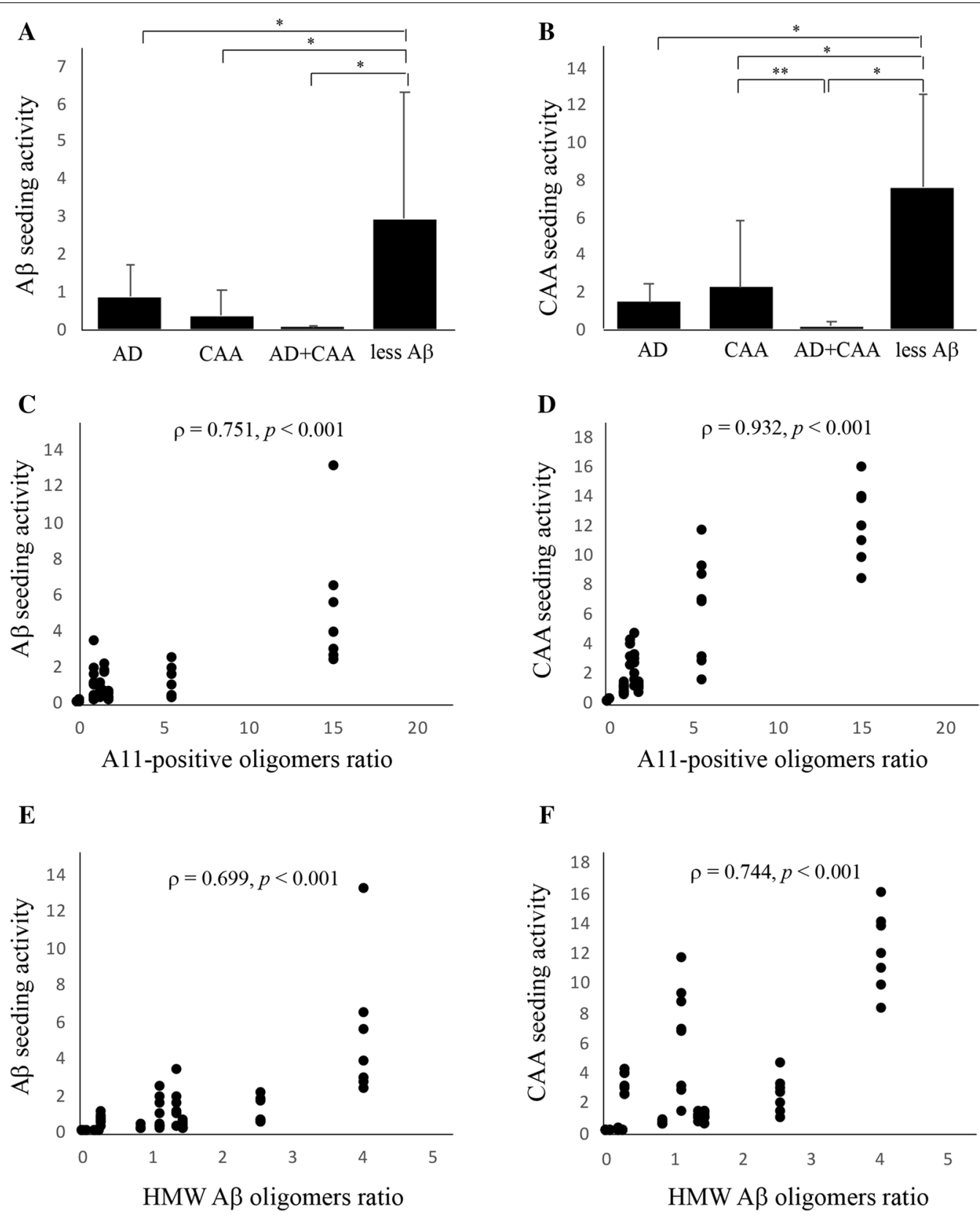

Fig. 7 Amyloid $\beta$ peptide ( $A \beta$ and cerebral amyloid angiopathy (CAA) seeding activities of the autopsied patients. $A \beta$ and $C A A$ seeding activities among the Alzheimer's disease (AD), CAA, AD +CAA, and less $A \beta$ groups $(\mathbf{A}$ and $\mathbf{B})$, and correlations between $A \beta$ or CAA seeding activities and $A 11$-positive oligomer ratios or high molecular weight $A \beta$ oligomers ratios $(\mathbf{C}-\mathbf{F})$. $A \beta$ and $C A A$ seeding activities in the less $A \beta$ group were significantly higher than those in the other 3 human autopsied patient groups ( $\mathbf{A}$ and $\mathbf{B}$ ). In terms of CAA seeding activity, the value in the $A D+C A A$ group was significantly lower than that in the CAA group (B). A 3 and CAA seeding activity was significantly correlated with the A11-positive oligomer ratio (C and $\mathbf{D})$ and the HMW A $\beta$ oligomer ratio (E and $\mathbf{F})$

Previous studies have shown that both parenchymal and vascular $A \beta$ depositions were observed in aged R1.40 mice, without obvious differences in the severity of A $\beta$ plaque accumulation and CAA [39]. Several pathological studies using autopsied patients with iatrogenic Creutzfeldt-Jakob disease (CJD) showed that $A \beta$ pathology might be transmitted from human to human through medical procedures, including intramuscular injection of growth hormones derived from cadaveric human pituitary glands and cadaveric dura mater grafting $[8,13,16,22,30,53]$. In cases of transmission of $A \beta$ pathology in humans, incidental $A \beta$ pathology 
A

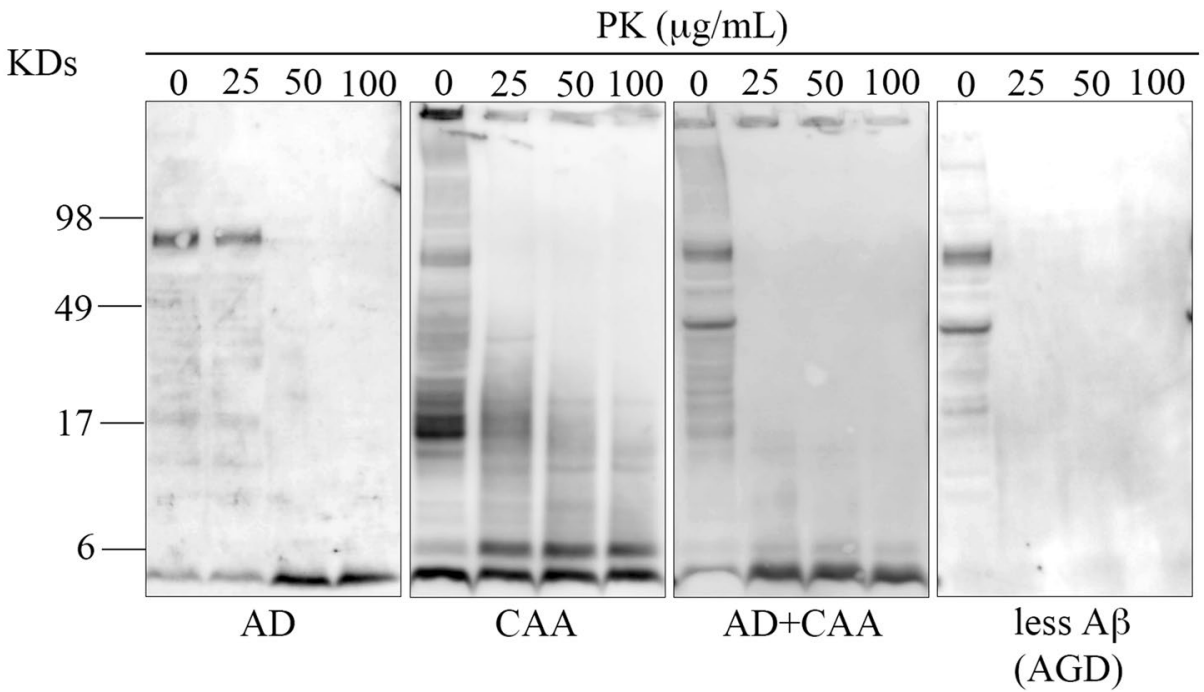

B

PK $(\mu \mathrm{g} / \mathrm{mL})$

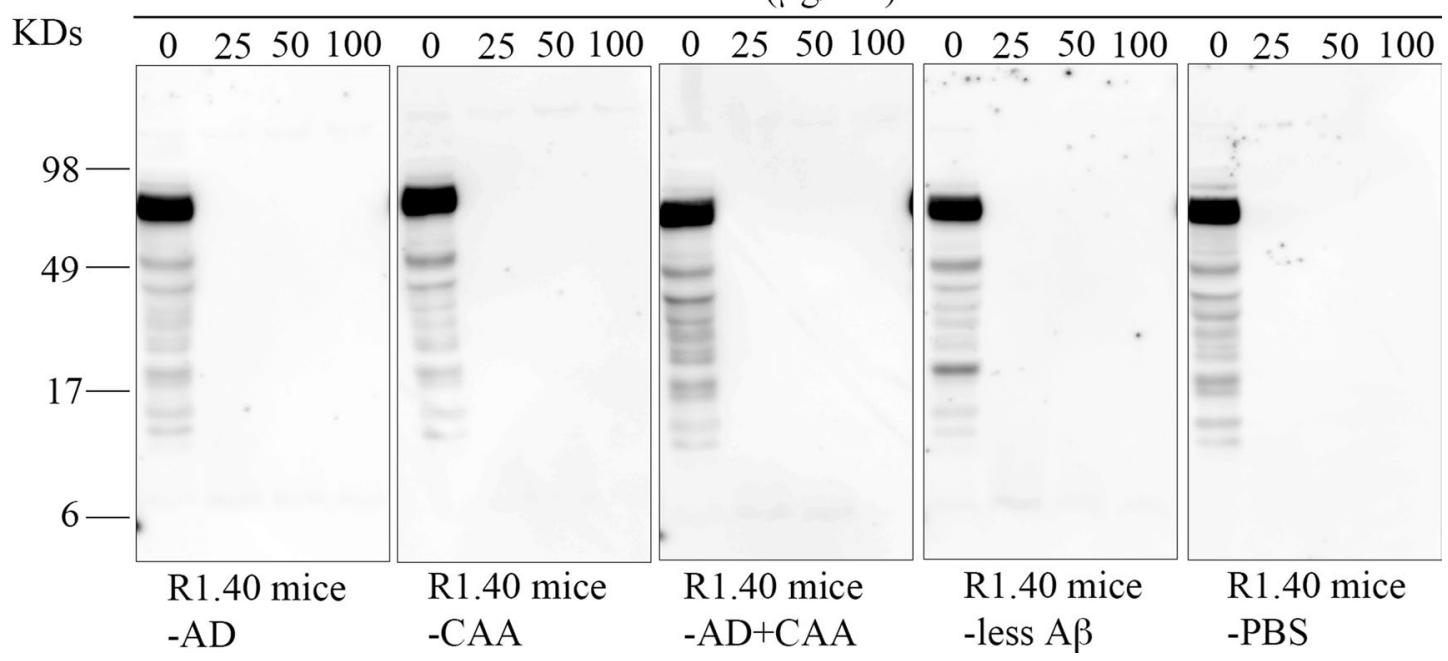

Fig. 8 Proteinase $K$ resistance of amyloid $\beta$ peptide $(A \beta)$ in human and mouse brain extracts. Human brain extracts of Alzheimer's disease (AD), cerebral amyloid angiopathy (CAA), AD + CAA and less $A \beta$ groups $(\mathbf{A})$ as well as mouse brain extracts of R1.40 mice-AD, R1.40 mice-CAA, R1.40 mice-AD + CAA, R1.40 mice-less A $\beta$ and R1.40 mice-PBS (B) were digested with 0, 25, 50, and $100 \mu \mathrm{g} / \mathrm{mL}$ of PK, and analyzed by Western blotting using antibodies against $A \beta_{1-16}(6 E 10,1: 5,000)$ as the primary antibodies. In the human brain extracts, $A \beta$ oligomers were digested by PK in all four groups (A). However, the signals of the $A \beta$ monomers and dimers were different among the 4 groups; the signals of the $A \beta$ monomers increased in the $A D$ and $A D+C A A$ groups, those of the $A \beta$ dimers increased in the CAA group, and almost no signal of $A \beta$ monomer and dimer signals were detected in the less $A \beta$ group $(\mathbf{A})$. On the other hand, in the mouse brain extracts, $A \beta$ oligomers were digested and the signals of the $A \beta$ dimers were lightly present $(\mathbf{B})$

recognized in patients with iatrogenic CJD was predominantly observed in blood vessels [8, 64]. Furthermore, most patients who developed CAA-related haemorrhage at a younger age had histories of neurosurgery with or without evidence of cadaveric dura mater grafting $[4,9,14,20,25,31,47,49,62,64]$. The results of the present study and the previously reported data on iatrogenic human-to-human transmission of
$A \beta$ pathology show that $A \beta$ fibrils aggregated by exogenous $A \beta$ seeds might deposit on vessels rather than the brain parenchyma, regardless of the $A \beta$ strain.

Interestingly, in the present study, parenchymal and vascular $A \beta$ depositions were observed in the R1.40 mice-less $A \beta$ group, although there were only a few diffuse plaques and CAA in the patients in the less $A \beta$ group. In particular, $A \beta$ and $C A A$ seeding activities in the 
less $A \beta$ group were significantly higher than they were in the other three groups. A previous study estimated the time course of $A \beta$ seeding activity in an $A D$ mouse model and showed that $A \beta$ seeding activity peaked sharply during the initial phase of $A \beta$ deposition [67], which was consistent with the results of the patients in the less $A \beta$ group in the present study, which should be in the initial phase of $A \beta$ deposition in the brain. Furthermore, another previous study showed that brain homogenates of pre-symptomatic or asymptomatic stages of AD accelerated $A \beta$ deposition in vivo [12]. In brain homogenates, soluble forms of $A \beta$, such as monomers and oligomers, as well as $A \beta$ fibrils, play important roles in $A \beta$ seeding $[15,35,41]$. A recent study reported the importance of $A \beta$ oligomers in the early and rapid seed-induced aggregation process as the first nucleation step in the absence of $\mathrm{A} \beta$ fibrils in the brains of AD mouse models [35]. In the present study, the A11-positive oligomer and HMW $A \beta$ oligomer ratios in the less $A \beta$ group were higher than they were in the other groups, and they had a significant positive correlation with $A \beta$ and CAA seeding activities. These results suggest that $A \beta$ oligomers play important roles in the initial phase of $A \beta$ deposition, and that the ratio of $A \beta$ oligomers increases in the brain during the early phase of $A \beta$ deposition in humans. Furthermore, our results indicate that $A \beta$ pathology may be transmitted from patients with little $A \beta$ pathology via neurosurgical procedures. Thus, the development of inactivation methods for $A \beta$ seeding activity to prevent iatrogenic transmission of $A \beta$ pathology is urgently required.

In the present study, the Apo E genotype of autopsied patients was $\varepsilon 3 / 3$ in seven patients (one in the CAA group, four in the $\mathrm{AD}+\mathrm{CAA}$ group, and two in the less $\mathrm{A} \beta$ group), $\varepsilon 3 / 4$ was in two patients (one in the $\mathrm{AD}$ group and another in the CAA group), and $\varepsilon 2 / 3$ in a patient in the CAA group. We found no influence of the Apo $E$ genotype on the pathological and biochemical features of $A \beta$ in the autopsied brain-injected R1.40 mice. We did not examine APP, preseniline (PS) 1 and PS 2 genes in all of the autopsied patients; however we believe that all patients did not have mutations in these genes because they were older and had no family history of AD.

In conclusion, exogenous $A \beta$ seeds from different $A \beta$ pathologies induced $A \beta$ deposition in the blood vessels rather than the brain parenchyma without being influenced by $A \beta$ strain-specific information, which might be a reason why CAA is a predominant feature of $A \beta$ pathology in iatrogenic transmission cases. Soluble $A \beta$ oligomers in the human brain play important roles in $A \beta$ transmission, and iatrogenic transmission of $A \beta$ pathology might occur in patients with little $A \beta$ pathology in the brain.

\section{Abbreviations}

AD: Alzheimer's disease; A 3 : Amyloid $\beta$ peptide; NFTs: Neurofibrillary tangles; CAA: Cerebral amyloid angiopathy; $A \beta 42$ : $A \beta$ with 42 amino acid peptides; $A \beta 40$ : $A \beta$ with 40 amino acid peptides; IPAD: Intramural peri-arterial drainage; PrP: Prion protein; Abnormal PrP: PrPSc; APP: Amyloid precursor protein; HCHWA: Hereditary cerebral haemorrhage with amyloidosis; APOE: Apolipoprotein E gene; CERAD: Consortium to Establish a Registry for AD; R1.40 mice: Homozygous R1.40 APP-transgenic mice; ELISA: Enzyme-linked immunosorbent assays; A11-positive oligomer ratio: The value of A11-positive oligomers was divided by the concentration of $A \beta 40+A \beta 42 ; H M W$ : High molecular weight; HMW A $\beta$ oligomers ratio: The concentration of HMW-positive oligomers was divided by the concentration of A $\beta 40+A \beta 42 ;$ PK: Proteinase K; R1.40 mice-AD: R1.40 mice injected with human brain extract from the patients in the AD group; R1.40 mice-CAA: R1.40 mice injected with human brain extract from the patients in the CAA group; R1.40 mice-AD + CAA: R1.40 mice injected with human brain extract from the patients in the AD + CAA group; R1.40 mice-less A $A$ : R1.40 mice injected with human brain extract from the patients in the less A group; R1.40 mice-PBS: R1.40 mice injected with PBS; AGD: Argyrophilic grain disease; PS: Preseniline.

\section{Acknowledgements}

We would like to thank Professor Mathias Jucker for his critical review and helpful suggestions for this manuscript. We would also like to thank Dr. Hisako Fujimura and Ms. Miyuki Honda for their excellent technical support. We also thank Editage (www.editage.com) for English language editing.

\section{Authors' contributions}

$\mathrm{TH}, \mathrm{KO}$, and MY contributed to the study concept and design. $\mathrm{TH}, \mathrm{KJH}, \mathrm{AH}, \mathrm{RG}$, and KS performed the experiments. Yl and MY recruited the autopsied human samples. TH and MY wrote the manuscript. All authors have edited and approved of the final manuscript.

\section{Funding}

This study was supported by JSPS KAKENHI Grant Number Grant Number JP17H04194 (MY) and by a grant-in-aid from the Takeda Science Foundation $(\mathrm{TH})$.

\section{Data availability statement}

The data that support the findings of this study are available from the corresponding author upon reasonable request.

\section{Declarations}

\section{Ethics approval and consent to participate}

In the present study, all studies of autopsied patients were conducted with the approval of the Institutional Ethics Committee at Kanazawa University (1276). All animal studies were approved by the Institutional Animal Experiment Committee of Kanazawa University (AP-132607) and performed in accordance with the Guidelines for the Care and Use of Laboratory Animals at Kanazawa University (Kanazawa, Japan).

\section{Consent for publication}

All authors have approved the manuscript and agree with its submission.

\section{Competing interests}

The authors declare no competing interests.

\section{Author details}

'Department of Neurology and Neurobiology of Aging, Kanazawa University Graduate School of Medical Sciences, 13-1 Takara-machi, Kanazawa 920-8640, Japan. ${ }^{2}$ Department of Internal Medicine, Division of Neurology, Showa University School of Medicine, Tokyo, Japan. ${ }^{3}$ Yokufukai Geriatric Hospital, Tokyo, Japan. ${ }^{4}$ Department of Internal Medicine, Division of Neurology, Kudanzaka Hospital, Tokyo, Japan.

Received: 27 August 2021 Accepted: 30 August 2021

Published online: 10 September 2021 


\section{References}

1. Albargothy NJ, Johnston DA, MacGregor-Sharp M, Weller RO, Verma A, Hawkes CA, Carare RO (2018) Convective influx/glymphatic system: trac ers injected into the CSF enter and leave the brain along separate periarterial basement membrane pathways. Acta Neuropathol 136:139-152. https://doi.org/10.1007/s00401-018-1862-7

2. Arriagada PV, Growdon JH, Hedley-Whyte ET, Hyman BT (1992) Neurofibrillary tangles but not senile plaques parallel duration and severity of Alzheimer's disease. Neurology 42:631-639. https://doi.org/10.1212/wnl. 42.3.631

3. Bakker EN, Bacskai BJ, Arbel-Ornath M, Aldea R, Bedussi B, Morris AW, Weller RO, Carare RO (2016) Lymphatic clearance of the brain: perivascular, paravascular and significance for neurodegenerative diseases. Cell Mol Neurobiol 36:181-194. https://doi.org/10.1007/s10571-015-0273-8

4. Banerjee G, Adams ME, Jaunmuktane Z, Alistair Lammie G, Turner B, Wani M, Sawhney IMS, Houlden H, Mead S, Brandner S et al (2019) Early onset cerebral amyloid angiopathy following childhood exposure to cadaveric dura. Ann Neurol 85:284-290. https://doi.org/10.1002/ana.25407

5. Braak H, Alafuzoffl, Arzberger T, Kretzschmar H, Del Tredici K (2006) Staging of Alzheimer disease-associated neurofibrillary pathology using paraffin sections and immunocytochemistry. Acta Neuropathol 112:389-404. https://doi.org/10.1007/s00401-006-0127-z

6. Bugiani O, Giaccone G, Rossi G, Mangieri M, Capobianco R, Morbin M, Mazzoleni G, Cupidi C, Marcon G, Giovagnoli A et al (2010) Hereditary cerebral hemorrhage with amyloidosis associated with the E693K mutation of APP. Arch Neurol 67:987-995. https://doi.org/10.1001/archneurol.2010. 178

7. Cacace R, Sleegers K, Van Broeckhoven C (2016) Molecular genetics of early-onset Alzheimer's disease revisited. Alzheimers Dement 12:733-748. https://doi.org/10.1016/j.jalz.2016.01.012

8. Cali I, Cohen ML, Haik S, Parchi P, Giaccone G, Collins SJ, Kofskey D, Wang H, McLean CA, Brandel JP et al (2018) latrogenic Creutzfeldt-Jakob disease with Amyloid- $\beta$ pathology: an international study. Acta Neuropathol Commun 6:5. https://doi.org/10.1186/s40478-017-0503-z

9. Campbell DM, Bruins S, Vogel H, Shuer LM, Wijman CA (2008) Intracerebral hemorrhage caused by cerebral amyloid angiopathy in a 53-year-old man. J Neurol 255:597-598. https://doi.org/10.1007/s00415-008-0742-9

10. Colby DW, Prusiner SB (2011) De novo generation of prion strains. Nat Rev Microbiol 9:771-777. https://doi.org/10.1038/nrmicro2650

11. Collinge J, Clarke AR (2007) A general model of prion strains and their pathogenicity. Science 318:930-936. https://doi.org/10.1126/science. 1138718

12. Duran-Aniotz C, Morales R, Moreno-Gonzalez I, Hu PP, Soto C (2013) Brains from non-Alzheimer's individuals containing amyloid deposits accelerate $A \beta$ deposition in vivo. Acta Neuropathol Commun 1:76. https://doi.org/10.1186/2051-5960-1-76

13. Duyckaerts C, Sazdovitch V, Ando K, Seilhean D, Privat N, Yilmaz Z, Peckeu L, Amar E, Comoy E, Maceski A et al (2018) Neuropathology of iatrogenic Creutzfeldt-Jakob disease and immunoassay of French cadaver-sourced growth hormone batches suggest possible transmission of tauopathy and long incubation periods for the transmission of $A \beta$ pathology. Acta Neuropathol 135:201-212. https://doi.org/10.1007/s00401-017-1791-x

14. Ehling R, Helbok R, Beer R, Lackner P, Broessner G, Pfausler B, Rocken C, Aguzzi A, Chemelli A, Schmutzhard E (2012) Recurrent intracerebral haemorrhage after coitus: a case report of sporadic cerebral amyloid angiopathy in a younger patient. Eur J Neurol 19:e29-31. https://doi.org/ 10.1111/j.1468-1331.2011.03624.x

15. Forny-Germano L, Lyra e Silva NM, Batista AF, Brito-Moreira J, Gralle M, Boehnke SE, Coe BC, Lablans A, Marques SA, Martinez AM et al (2014) Alzheimer's disease-like pathology induced by amyloid- $\beta$ oligomers in nonhuman primates. J Neurosci 34: 13629-13643, https://doi.org/10. 1523/JNEUROSCI.1353-14.2014

16. Frontzek K, Lutz MI, Aguzzi A, Kovacs GG, Budka H (2016) Amyloid- $\beta$ pathology and cerebral amyloid angiopathy are frequent in iatrogenic Creutzfeldt-Jakob disease after dural grafting. Swiss Med Wkly 146:w14287. https://doi.org/10.4414/smw.2016.14287

17. Fukumoto H, Tokuda T, Kasai T, Ishigami N, Hidaka H, Kondo M, Allsop D, Nakagawa M (2010) High-molecular-weight $\beta$-amyloid oligomers are elevated in cerebrospinal fluid of Alzheimer patients. FASEB J 24:27162726. https://doi.org/10.1096/fi.09-150359
18. Glabe CG (2008) Structural classification of toxic amyloid oligomers. J Biol Chem 283:29639-29643. https://doi.org/10.1074/jbc.R800016200

19. Hamaguchi T, Eisele YS, Varvel NH, Lamb BT, Walker LC, Jucker M (2012) The presence of $A \beta$ seeds, and not age per se, is critical to the initiation of $A \beta$ deposition in the brain. Acta Neuropathol 123:31-37. https://doi.org/ 10.1007/s00401-011-0912-1

20. Hamaguchi T, Komatsu J, Sakai K, Noguchi-Shinohara M, Aoki S, Ikeuchi T, Yamada M (2019) Cerebral hemorrhagic stroke associated with cerebral amyloid angiopathy in young adults about 3 decades after neurosurgeries in their infancy. J Neurol Sci 399:3-5. https://doi.org/10.1016/j.jns. 2019.01.051

21. Hamaguchi T, Ono K, Murase A, Yamada M (2009) Phenolic compounds prevent Alzheimer's pathology through different effects on the amyloid- $\beta$ aggregation pathway. Am J Pathol 175:2557-2565. https://doi. org/10.2353/ajpath.2009.090417

22. Hamaguchi T, Taniguchi Y, Sakai K, Kitamoto T, Takao M, Murayama S, Iwasaki Y, Yoshida M, Shimizu H, Kakita A et al (2016) Significant association of cadaveric dura mater grafting with subpial $A \beta$ deposition and meningeal amyloid angiopathy. Acta Neuropathol 132:313-315. https://doi.org/10. 1007/s00401-016-1588-3

23. Head MW, Ironside JW (2012) Review: Creutzfeldt-Jakob disease: prion protein type, disease phenotype and agent strain. Neuropathol Appl Neurobiol 38:296-310. https://doi.org/10.1111/j.1365-2990.2012.01265.x

24. Heilbronner G, Eisele YS, Langer F, Kaeser SA, Novotny R, Nagarathinam A, Aslund A, Hammarstrom P, Nilsson KP, Jucker M (2013) Seeded strain-like transmission of $\beta$-amyloid morphotypes in APP transgenic mice. EMBO Rep 14:1017-1022. https://doi.org/10.1038/embor.2013.137

25. Herve D, Porche M, Cabrejo L, Guidoux C, Tournier-Lasserve E, Nicolas G, Adle-Biassette H, Plu I, Chabriat H, Duyckaerts C (2018) Fatal A cerebral amyloid angiopathy 4 decades after a dural graft at the age of 2 years. Acta Neuropathol 135:801-803. https://doi.org/10.1007/ s00401-018-1828-9

26. Herzig MC, Van Nostrand WE, Jucker M (2006) Mechanism of cerebral $\beta$-amyloid angiopathy: murine and cellular models. Brain Pathol 16:40-54. https://doi.org/10.1111/j.1750-3639.2006.tb00560.x

27. Herzig MC, Winkler DT, Burgermeister P, Pfeifer M, Kohler E, Schmidt SD, Danner S, Abramowski D, Sturchler-Pierrat C, Burki Ket al (2004) A $\beta$ is targeted to the vasculature in a mouse model of hereditary cerebral hemorrhage with amyloidosis. Nat Neurosci 7:954-960. https://doi.org/ 10.1038/nn1302

28. Hyman BT, Phelps CH, Beach TG, Bigio EH, Cairns NJ, Carrillo MC, Dickson DW, Duyckaerts C, Frosch MP, Masliah E et al (2012) National Institute on Aging-Alzheimer's Association guidelines for the neuropathologic assessment of Alzheimer's disease. Alzheimers Dement 8:1-13. https://doi.org/ 10.1016/j.jalz.2011.10.007

29. Itoh Y, Yamada M, Suematsu N, Matsushita M, Otomo E (1996) Influence of apolipoprotein E genotype on cerebral amyloid angiopathy in the elderly. Stroke 27:216-218. https://doi.org/10.1161/01.str.27.2.216

30. Jaunmuktane Z, Mead S, Ellis M, Wadsworth JD, Nicoll AJ, Kenny J, Launchbury F, Linehan J, Richard-Loendt A, Walker AS et al (2015) Evidence for human transmission of amyloid- $\beta$ pathology and cerebral amyloid angiopathy. Nature 525:247-250. https://doi.org/10.1038/natur e15369

31. Jaunmuktane Z, Quaegebeur A, Taipa R, Viana-Baptista M, Barbosa R, Koriath C, Sciot R, Mead S, Brandner S (2018) Evidence of amyloid- $\beta$ cerebral amyloid angiopathy transmission through neurosurgery. Acta Neuropathol 135:671-679. https://doi.org/10.1007/s00401-018-1822-2

32. Jucker M, Walker LC (2018) Propagation and spread of pathogenic protein assemblies in neurodegenerative diseases. Nat Neurosci 21:1341-1349. https://doi.org/10.1038/s41593-018-0238-6

33. Kalaria RN (2016) Neuropathological diagnosis of vascular cognitive impairment and vascular dementia with implications for Alzheimer's disease. Acta Neuropathol 131:659-685. https://doi.org/10.1007/ s00401-016-1571-z

34. Kasai T, Kondo M, Ishii R, Tanaka A, Ataka S, Shimada H, Tomiyama T, Mori H, Taylor M, Allsop D et al (2017) A $\beta$ levels in the jugular vein and high molecular weight A $\beta$ oligomer levels in CSF can be used as biomarkers to indicate the anti-amyloid effect of IVIg for Alzheimer's disease. PLoS ONE 12:e0174630. https://doi.org/10.1371/journal.pone.0174630 
35. Katzmarski N, Ziegler-Waldkirch S, Scheffler N, Witt C, Abou-Ajram C, Nuscher B, Prinz M, Haass C, Meyer-Luehmann M (2020) A 3 oligomers trigger and accelerate $A \beta$ seeding. Brain Pathol 30:36-45. https://doi.org/ 10.1111/bpa.12734

36. Kayed R, Head E, Sarsoza F, Saing T, Cotman CW, Necula M, Margol L, Wu J, Breydo L, Thompson JL et al (2007) Fibril specific, conformation dependent antibodies recognize a generic epitope common to amyloid fibrils and fibrillar oligomers that is absent in prefibrillar oligomers. Mol Neurodegener 2:18. https://doi.org/10.1186/1750-1326-2-18

37. Kayed R, Head E, Thompson JL, McIntire TM, Milton SC, Cotman CW, Glabe CG (2003) Common structure of soluble amyloid oligomers implies common mechanism of pathogenesis. Science 300:486-489. https://doi. org/10.1126/science.1079469

38. Kollmer M, Close W, Funk L, Rasmussen J, Bsoul A, Schierhorn A, Schmidt M, Sigurdson CJ, Jucker M, Fandrich M (2019) Cryo-EM structure and polymorphism of A $A$ amyloid fibrils purified from Alzheimer's brain tissue. Nat Commun 10:4760. https://doi.org/10.1038/s41467-019-12683-8

39. Kulnane LS, Lamb BT (2001) Neuropathological characterization of mutant amyloid precursor protein yeast artificial chromosome transgenic mice. Neurobiol Dis 8:982-992. https://doi.org/10.1006/nbdi.2001.0446

40. Lamb BT, Call LM, Slunt HH, Bardel KA, Lawler AM, Eckman CB, Younkin SG, Holtz G, Wagner SL, Price DL et al (1997) Altered metabolism of familial Alzheimer's disease-linked amyloid precursor protein variants in yeast artificial chromosome transgenic mice. Hum Mol Genet 6:1535-1541. https://doi.org/10.1093/hmg/6.9.1535

41. Langer F, Eisele YS, Fritschi SK, Staufenbiel M, Walker LC, Jucker M (2011) Soluble $A \beta$ seeds are potent inducers of cerebral $\beta$-amyloid deposition. J Neurosci 31:14488-14495. https://doi.org/10.1523/JNEUROSCI.3088-11. 2011

42. Levy E, Carman MD, Fernandez-Madrid IJ, Power MD, Lieberburg I, van Duinen SG, Bots GT, Luyendijk W, Frangione B (1990) Mutation of the Alzheimer's disease amyloid gene in hereditary cerebral hemorrhage, Dutch type. Science 248:1124-1126. https://doi.org/10.1126/science.2111584

43. Love S, Chalmers K, Ince P, Esiri M, Attems J, Jellinger K, Yamada M, McCarron M, Minett T, Matthews F et al (2014) Development, appraisal, validation and implementation of a consensus protocol for the assessment of cerebral amyloid angiopathy in post-mortem brain tissue. Am 」 Neurodegener Dis 3:19-32

44. Maat-Schieman ML, van Duinen SG, Bornebroek M, Haan J, Roos RA (1996) Hereditary cerebral hemorrhage with amyloidosis-Dutch type (HCHWA-D): II-A review of histopathological aspects. Brain Pathol 6:115-120. https://doi.org/10.1111/j.1750-3639.1996.tb00794.x

45. Meyer-Luehmann M, Coomaraswamy J, Bolmont T, Kaeser S, Schaefer C, Kilger E, Neuenschwander A, Abramowski D, Frey P, Jaton AL et al (2006) Exogenous induction of cerebral $\beta$-amyloidogenesis is governed by agent and host. Science 313:1781-1784. https://doi.org/10.1126/science. 1131864

46. Mirra SS, Heyman A, McKeel D, Sumi SM, Crain BJ, Brownlee LM, Vogel FS, Hughes JP, van Belle G, Berg L (1991) The Consortium to establish a registry for Alzheimer's Disease (CERAD). Part II. Standardization of the neuropathologic assessment of Alzheimer's disease. Neurology 41:479-486. https://doi.org/10.1212/wnl.41.4.479

47. Nakayama Y, Mineharu Y, Arawaka Y, Nishida S, Tsuji H, Miyake H, Yamaguchi M, Minamiguchi S, Takagi Y, Miyamoto S (2017) Cerebral amyloid angiopathy in a young man with a history of traumatic brain injury: a case report and review of the literature. Acta Neurochir (Wien) 159:15-18. https://doi.org/10.1007/s00701-016-3004-0

48. Parchi P, Cescatti M, Notari S, Schulz-Schaeffer WJ, Capellari S, Giese A, Zou WQ, Kretzschmar H, Ghetti B, Brown P (2010) Agent strain variation in human prion disease: insights from a molecular and pathological review of the National Institutes of Health series of experimentally transmitted disease. Brain 133:3030-3042. https://doi.org/10.1093/brain/awq234

49. Purrucker JC, Hund E, Ringleb PA, Hartmann C, Rohde S, Schonland S, Steiner T (2013) Cerebral amyloid angiopathy-an underdiagnosed entity in younger adults with lobar intracerebral hemorrhage? Amyloid 20:45-47. https://doi.org/10.3109/13506129.2012.746937
50. Qiang W, Yau WM, Lu JX, Collinge J, Tycko R (2017) Structural variation in amyloid- $\beta$ fibrils from Alzheimer's disease clinical subtypes. Nature 541:217-221. https://doi.org/10.1038/nature20814

51. Rasmussen J, Mahler J, Beschorner N, Kaeser SA, Hasler LM, Baumann F, Nystrom S, Portelius E, Blennow K, Lashley T et al (2017) Amyloid polymorphisms constitute distinct clouds of conformational variants in different etiological subtypes of Alzheimer's disease. Proc Natl Acad Sci USA 114:13018-13023. https://doi.org/10.1073/pnas.1713215114

52. Rasmussen MK, Mestre H, Nedergaard M (2018) The glymphatic pathway in neurological disorders. Lancet Neurol 17:1016-1024. https://doi.org/ 10.1016/S1474-4422(18)30318-1

53. Ritchie DL, Adlard P, Peden AH, Lowrie S, Le Grice M, Burns K, Jackson RJ, Yull H, Keogh MJ, Wei W et al (2017) Amyloid- $\beta$ accumulation in the CNS in human growth hormone recipients in the UK. Acta Neuropathol 134:221-240. https://doi.org/10.1007/s00401-017-1703-0

54. Sakai K, Ueda M, Fukushima W, Tamaoka A, Shoji M, Ando Y, Yamada M (2019) Nationwide survey on cerebral amyloid angiopathy in Japan. Eur J Neurol 26:1487-1493. https://doi.org/10.1111/ene.14031

55. Selkoe DJ, Hardy J (2016) The amyloid hypothesis of Alzheimer's disease at 25 years. EMBO Mol Med 8:595-608. https://doi.org/10.15252/emmm. 201606210

56. Stohr J, Condello C, Watts JC, Bloch L, Oehler A, Nick M, DeArmond SJ, Giles K, DeGrado WF, Prusiner SB (2014) Distinct synthetic A $\beta$ prion strains producing different amyloid deposits in bigenic mice. Proc Natl Acad Sci USA 111:10329-10334. https://doi.org/10.1073/pnas.1408968111

57. Suzuki N, Iwatsubo T, Odaka A, Ishibashi Y, Kitada C, Ihara Y (1994) High tissue content of soluble $\beta$ 1-40 is linked to cerebral amyloid angiopathy. Am J Pathol 145:452-460

58. Thal DR, Rub U, Orantes M, Braak H (2002) Phases of Aß-deposition in the human brain and its relevance for the development of AD. Neurology 58:1791-1800. https://doi.org/10.1212/wnl.58.12.1791

59. Vinters HV, Gilbert JJ (1983) Cerebral amyloid angiopathy: incidence and complications in the aging brain. II. The distribution of amyloid vascular changes. Stroke 14:924-928. https://doi.org/10.1161/01.str.14.6.924

60. Watts JC, Condello C, Stohr J, Oehler A, Lee J, DeArmond SJ, Lannfelt L, Ingelsson M, Giles K, Prusiner SB (2014) Serial propagation of distinct strains of A $\beta$ prions from Alzheimer's disease patients. Proc Natl Acad Sci USA 111:10323-10328. https://doi.org/10.1073/pnas.1408900111

61. Weller RO, Massey A, Newman TA, Hutchings M, Kuo YM, Roher AE (1998) Cerebral amyloid angiopathy: amyloid $\beta$ accumulates in putative interstitial fluid drainage pathways in Alzheimer's disease. Am J Pathol 153:725-733. https://doi.org/10.1016/s0002-9440(10)65616-7

62. Wong MP, Ng TH, Chan KH (1991) Cerebral amyloid angiopathy and spontaneous intracerebral haemorrhage. Report of a sporadic case in a young Chinese. Clin Neurol Neurosurg 93:133-136. https://doi.org/10. 1016/0303-8467(91)90054-s

63. Yamada M (2015) Cerebral amyloid angiopathy: emerging concepts. J Stroke 17:17-30. https://doi.org/10.5853/jos.2015.17.1.17

64. Yamada M, Hamaguchi T, Sakai K (2019) Acquired cerebral amyloid angiopathy: an emerging concept. Prog Mol Biol Transl Sci 168:85-95. https:// doi.org/10.1016/bs.pmbts.2019.05.012

65. Yamada M, Naiki H (2012) Cerebral amyloid angiopathy. Prog Mol Biol Transl Sci 107:41-78. https://doi.org/10.1016/B978-0-12-385883-2. 00006-0

66. Yamada M, Tsukagoshi H, Otomo E, Hayakawa M (1987) Cerebral amyloid angiopathy in the aged. J Neurol 234:371-376. https://doi.org/10.1007/ bfo0314080

67. Ye L, Rasmussen J, Kaeser SA, Marzesco AM, Obermuller U, Mahler J, Schelle J, Odenthal J, Kruger C, Fritschi SK et al (2017) Aß seeding potency peaks in the early stages of cerebral $\beta$-amyloidosis. EMBO Rep 18:1536-1544. https://doi.org/10.15252/embr.201744067

\section{Publisher's Note}

Springer Nature remains neutral with regard to jurisdictional claims in published maps and institutional affiliations. 